ARTICLE

\title{
Aluminum-copper alloy anode materials for high-energy aqueous aluminum batteries
}

\author{
Qing Ran (10) 1,3, Hang Shi (1) 1,3, Huan Meng ${ }^{1,3}$, Shu-Pei Zeng ${ }^{1}$, Wu-Bin Wan (1) 1, Wei Zhang (1) 1, Zi Wen (1) 1, \\ Xing-You Lang $\mathbb{1}^{1,2 \bowtie} \&$ Qing Jiang ${ }^{1 凶}$
}

Aqueous aluminum batteries are promising post-lithium battery technologies for large-scale energy storage applications because of the raw materials abundance, low costs, safety and high theoretical capacity. However, their development is hindered by the unsatisfactory electrochemical behaviour of the Al metal electrode due to the presence of an oxide layer and hydrogen side reaction. To circumvent these issues, we report aluminum-copper alloy lamellar heterostructures as anode active materials. These alloys improve the Al-ion electrochemical reversibility (e.g., achieving dendrite-free Al deposition during stripping/plating cycles) by using periodic galvanic couplings of alternating anodic $\alpha$-aluminum and cathodic intermetallic $\mathrm{Al}_{2} \mathrm{Cu}$ nanometric lamellas. In symmetric cell configuration with a low oxygen concentration (i.e., $0.13 \mathrm{mg} \mathrm{L}^{-1}$ ) aqueous electrolyte solution, the lamella-nanostructured eutectic $\mathrm{Al}_{82} \mathrm{Cu}_{18}$ alloy electrode allows Al stripping/plating for $2000 \mathrm{~h}$ with an overpotential lower than $\pm 53 \mathrm{mV}$. When the $\mathrm{Al}_{82} \mathrm{Cu}_{18}$ anode is tested in combination with an $\mathrm{Al}_{x} \mathrm{MnO}_{2}$ cathode material, the aqueous full cell delivers specific energy of $\sim 670 \mathrm{Wh} \mathrm{kg}^{-1}$ at $100 \mathrm{~mA} \mathrm{~g}^{-1}$ and an initial discharge capacity of $\sim 400 \mathrm{mAh} \mathrm{g}^{-1}$ at $500 \mathrm{~mA} \mathrm{~g}^{-1}$ with a capacity retention of $83 \%$ after 400 cycles.

\footnotetext{
${ }^{1}$ Key Laboratory of Automobile Materials (Jilin University), Ministry of Education, School of Materials Science and Engineering, and Electron Microscopy Center, Jilin University, Changchun 130022, China. ${ }^{2}$ State Key Laboratory of Automotive Simulation and Control, Jilin University, Changchun 130022 , China.

${ }^{3}$ These authors contributed equally: Qing Ran, Hang Shi, Huan Meng. email: xylang@jlu.edu.cn; jiangq@jlu.edu.cn
} 
S afe and reliable large-scale energy storage technologies are indispensable for many emerging applications including electric vehicles and grid integration of intermittent renewable energy sources ${ }^{1,2}$. Although lithium-ion batteries (LIBs) dominate the present energy-storage landscape, they are far from meeting the needs of large-scale energy storage due to their inherent issues such as high cost and scarcity of lithium resources, as well as safety problems associated with highly toxic and flammable organic electrolytes $^{2-4}$. This dilemma has led to the recent boom in the development of alternative battery technologies ${ }^{2,5}$, especially aqueous rechargeable batteries that use monovalent $\left(\mathrm{Na}^{+6}, \mathrm{~K}^{+}{ }^{7}\right)$ or multivalent $\left(\mathrm{Mg}^{2+8,9}, \mathrm{Al}^{3+10-13}, \mathrm{Ca}^{2+15}, \mathrm{Zn}^{2+16-20}\right)$ cations as charge carriers in low-cost and safe water-based electrolytes ${ }^{21,22}$. Among these post-lithium energy storage devices, aqueous rechargeable aluminum-metal batteries (AR-AMBs) hold great promise as safe power sources for transportation and viable solutions for grid-level energy storage because of metallic aluminum (Al) offering high volumetric/gravimetric capacities $\left(8056 \mathrm{mAh} \mathrm{cm}^{-3}\right.$ and $2981 \mathrm{mAh}^{-1}$ ) by a three-electron redox reaction ${ }^{10,13,21,23-26}$, in addition to its low cost and high Earth abundance ${ }^{10,21}$. Despite various cathode materials including titanium oxides ${ }^{27,28}$, bismuth oxides $^{29}$, vanadium oxides ${ }^{30}$, aluminum manganese oxides ${ }^{12,15,22,31}$, and Prussian blue analogues ${ }^{32,33}$ have been explored for reversible $\mathrm{Al}^{3+}$ storage/delivery in aqueous electrolytes via intercalation or conversion reaction mechanisms ${ }^{10,13,22}$, these AR-AMBs generally exhibit low Coulombic efficiency and inadequate cycling stability, even in water-in-salt aluminum trifluoromethanesulfonate $\left(\mathrm{Al}(\mathrm{OTF})_{3}\right)$ electrolytes ${ }^{10-12,22-25}$. Their poor rechargeability primarily results from irreversibility of $\mathrm{Al}$ anode due to inherent formation of the insulating and passivating aluminum oxide (alumina) layer that substantially limits $\mathrm{Al}^{3+}$ transportation for subsequent $\mathrm{Al}$ stripping/plating $10,11,22-25,34$. While increasing potentials to drive ion transport through such alumina layer, there concomitantly take place hydrogen evolution reaction and corrosion reaction to continuously deplete aqueous electrolyte and $\mathrm{Al}$ anode ${ }^{10,11,23,24}$. Despite the native oxide layer could be moderated by alloying of $\mathrm{Al}$ and small amount of other elements ${ }^{14,23,24}$ or by constructing artificial solid electrolyte interphases ${ }^{11,35}$, these ineluctable side reactions essentially impede widespread implementation of aqueous aluminum-metal batteries as a rechargeable energy-storage technology for practical use. Therefore, it is highly desirable to explore feasible strategies to improve $\mathrm{Al}$ reversibility of $\mathrm{Al}$-based anode materials for high-performance AR-AMBs.

Here we demonstrate that eutectic engineering of Al-based alloy anodes improves their $\mathrm{Al}$ reversibility in aqueous electrolyte, based on eutectic $\mathrm{Al}_{82} \mathrm{Cu}_{18}$ (at\%) alloy $\left(\mathrm{E}-\mathrm{Al}_{82} \mathrm{Cu}_{18}\right.$ ) with a lamellar nanostructure consisting of alternating $\alpha-\mathrm{Al}$ and intermetallic $\mathrm{Al}_{2} \mathrm{Cu}$ nanolamellas. Such nanostructure enlists the $\mathrm{E}-\mathrm{Al}_{82} \mathrm{Cu}_{18}$ electrode to have periodically localized galvanic couples of anodic $\alpha$ $\mathrm{Al}$ and cathodic $\mathrm{Al}_{2} \mathrm{Cu}$ by making use of their distinct corrosion potentials $\left(-1.65 \mathrm{~V} \text { and }-1.2 \mathrm{~V} \text { versus } \mathrm{H}^{+} / \mathrm{H}_{2}\right)^{36,37}$. Therein, the more-noble $\mathrm{Al}_{2} \mathrm{Cu}$ lamellas serve as electron transfer pathway to facilitate $\mathrm{Al}$ stripping from the constituent less-noble $\mathrm{Al}$ lamellas and work as nanopatterns to guide subsequent dendrite-free $\mathrm{Al}$ plating, enabling improved $\mathrm{Al}$ reversibility at low potentials especially in an aqueous $\mathrm{Al}(\mathrm{OTF})_{3}$ electrolyte with a low oxygen concentration of $0.13 \mathrm{mg} \mathrm{L}^{-1}$, which significantly inhibits hydrogen evolution reaction and further formation of the passivating oxide layer. As a result, the $\mathrm{E}-\mathrm{Al}_{82} \mathrm{Cu}_{18}$ electrodes exhibit improved $\mathrm{Al}$ stripping/plating behaviors, with the overpotential of as low as $\sim 53 \mathrm{mV}$ and the Coulombic efficiency of $\sim 100 \%$, for more than $2000 \mathrm{~h}$. When assembled with $\mathrm{Al}_{x} \mathrm{MnO}_{2}$ cathode, the $\mathrm{E}-\mathrm{Al}_{82} \mathrm{Cu}_{18}$ electrodes render full cells to achieve high specific energy of $\sim 670 \mathrm{Wh} \mathrm{kg}^{-1}$ or energy density of $815 \mathrm{Wh} \mathrm{L}^{-1}$ at $100 \mathrm{~mA} \mathrm{~g}^{-1}$ (based on the loading mass of $\mathrm{Al}_{x} \mathrm{MnO}_{2}$ or the volume of cathode), and retain $83 \%$ capacity after 400 cycles. The facile and scalable metallurgical technology of eutectic engineering opens a way to develop high-performance alloy anodes for next-generation aqueous rechargeable metal batteries.

\section{Results}

Physicochemical characterizations of the Al-Cu alloys. Al metal is one of the most attractive anode materials in post-lithium batteries in view of its numerous merits, such as low cost and high Earth abundance, as well as high charge density and gravimetric/volumetric capacities, compared with $\mathrm{Na}, \mathrm{K}$, and Zn (Fig. 1a and Supplementary Table 1$)^{10,21,24,25}$. To tackle its inherent irreversibility issue due to the oxide layer, here we design periodically aligned metallic/intermetallic $\mathrm{Al} / \mathrm{Al}_{2} \mathrm{Cu}$ galvanic couples in $\mathrm{E}-\mathrm{Al}_{82} \mathrm{Cu}_{18}$ alloy to improve the $\mathrm{Al}$ stripping/plating in AR-AMBs, distinguishing from eutectic $\mathrm{Zn}$-Sn alloy to minimize active materials pulverization and subsequent loss of electrical contact in $\mathrm{LIBs}^{38}$, and eutectic $\mathrm{Zn}$ $\mathrm{Al}$ alloy to address dendrite issue of $\mathrm{Zn}$ metal anode in aqueous rechargeable zinc-ion batteries ${ }^{39}$. With the assumption that all $\mathrm{Al}$ atoms can take part in the electrochemical stripping/plating, the theoretical volumetric and gravimetric capacities of the $\mathrm{E}-\mathrm{Al}_{82} \mathrm{Cu}_{18}$ alloy are estimated to reach $7498 \mathrm{mAh} \mathrm{cm}^{-3}$ and $1965 \mathrm{mAh} \mathrm{g}^{-1}$.

The $\mathrm{E}-\mathrm{Al}_{82} \mathrm{Cu}_{18}$ alloy is prepared by arc-melting pure $\mathrm{Al}$ (99.994\%) and $\mathrm{Cu}$ (99.996\%) metals with a eutectic composition of 82:18 (at\%), followed by a water cycle-assisted furnace cooling for the formation of immiscible $\alpha-\mathrm{Al}$ and $\mathrm{Al}_{2} \mathrm{Cu}$ eutectoid via an eutectic solidification reaction (Fig. $1 \mathrm{~b}, \mathrm{c})^{40,41}$. X-ray diffraction (XRD) characterization demonstrates the spontaneously separated $\alpha-\mathrm{Al}$ and $\mathrm{Al}_{2} \mathrm{Cu}$ phases in the as-prepared $\mathrm{E}-\mathrm{Al}_{82} \mathrm{Cu}_{18}$ alloy (Fig. 1d), with two sets of characteristic XRD patterns corresponding to the (111), (200), (220), and (311) planes of face-centered cubic (fcc) Al metal (JCPDS 04-0787) and the (110), (200), (211), (112), (202), (222), (420), (402) planes of body-centered tetragonal (bct) $\mathrm{Al}_{2} \mathrm{Cu}$ intermetallic compound (JCPDS 25-0012), respectively. The optical micrograph of $\mathrm{E}-\mathrm{Al}_{82} \mathrm{Cu}_{18}$ alloy sheets reveals that the eutectic solidification produces an ordered lamellar nanostructure of alternating $\alpha-\mathrm{Al}$ and intermetallic $\mathrm{Al}_{2} \mathrm{Cu}$ lamellas with thicknesses of $\sim 150 \mathrm{~nm}$ and $\sim 270 \mathrm{~nm}$ (Fig. 1e and Supplementary Fig. 1), i.e., the lamellar spacing of $\sim 420 \mathrm{~nm}$. This microstructure is also illustrated by scanning electron microscope (SEM) backscattered electron image and its corresponding energy dispersive spectroscopy (EDS) elemental mapping of $\mathrm{Al}$ and $\mathrm{Cu}$. As shown in Fig. 1f, both $\mathrm{Al}$ and $\mathrm{Cu}$ atoms periodically distribute in the $\mathrm{E}-\mathrm{Al}_{82} \mathrm{Cu}_{18}$ alloy, depending on the presence of alternating $\mathrm{Al}$ and $\mathrm{Al}_{2} \mathrm{Cu}$ nanolamellas. Figure $1 \mathrm{~g}$ shows a high-resolution transmission electron microscope (HRTEM) image of $\mathrm{Al} / \mathrm{Al}_{2} \mathrm{Cu}$ interfacial region, viewed along their $<111>$ and $<10 \overline{2}>$ zone axis. In view of the phase separation triggered by eutectic reaction ${ }^{40,41}$, there present distinctly isolated monometallic $\mathrm{Al}$ and intermetallic $\mathrm{Al}_{2} \mathrm{Cu}$ regions, which are identified by their fast Fourier transform (FFT) patterns of fcc and bct crystallographic structures (Fig. 1h, i). Owing to the high oxophilicity of $\mathrm{Al}^{10,11,22-25,34,35}$, it is reasonable to observe thin amorphous oxide shell with a thickness of $\sim 4 \mathrm{~nm}$ on the constituent $\alpha$-Al lamellas of the $\mathrm{E}_{-} \mathrm{Al}_{82} \mathrm{Cu}_{18}$ alloy (Fig. $1 \mathrm{j}, \mathrm{k}$ ). Nevertheless, X-ray photoelectron spectroscopy (XPS) measurements indicate that in addition to the chemical state of $\mathrm{Al}^{3+}$ due to the formation of $\mathrm{Al}_{2} \mathrm{O}_{3}$ layer, the $\mathrm{Al}$ and $\mathrm{Cu}$ components at the surface layer of $\mathrm{E}-\mathrm{Al}_{82} \mathrm{Cu}_{18}$ alloy are primarily in the metallic states because of the conductive $\mathrm{Al}_{2} \mathrm{Cu}$ lamellas (Supplementary Fig. 2a, b), which not only facilitate electron transfer through the amorphous $\mathrm{Al}_{2} \mathrm{O}_{3}$ surface layer but pair with their neighboring $\mathrm{Al}$ lamellas to form localized $\mathrm{Al} / \mathrm{Al}_{2} \mathrm{Cu}$ galvanic couples in charge/discharge processes ${ }^{36,37,42}$.

Electrochemical characterizations of the Al-Cu alloys. To investigate the influence of passivating oxide layer on the Al stripping/plating behaviors of Al-based electrodes, electrochemical 
a

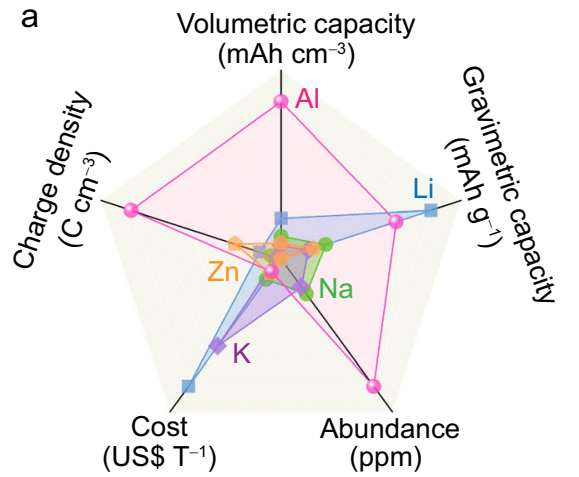

b
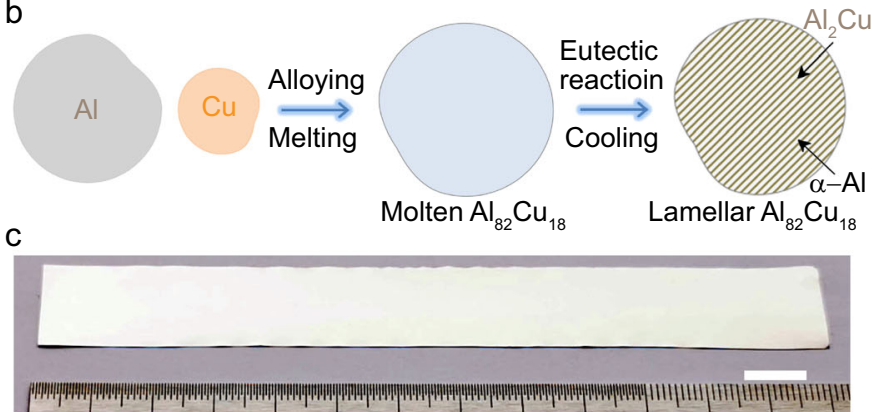

d

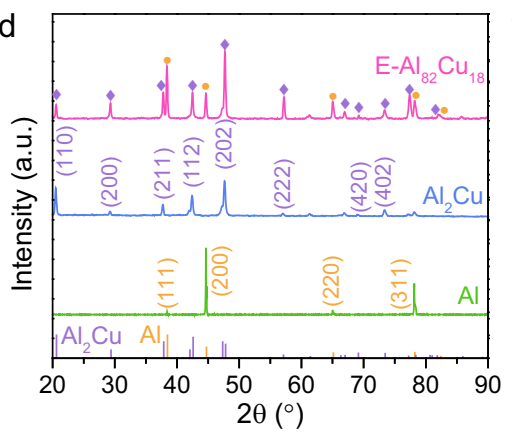

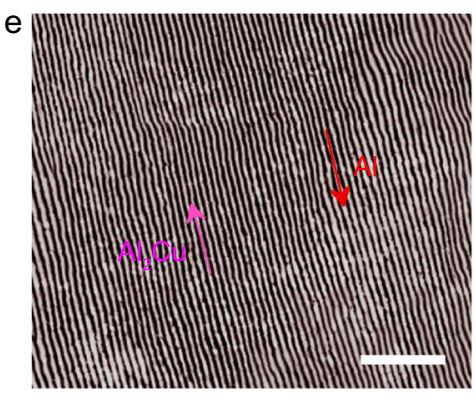
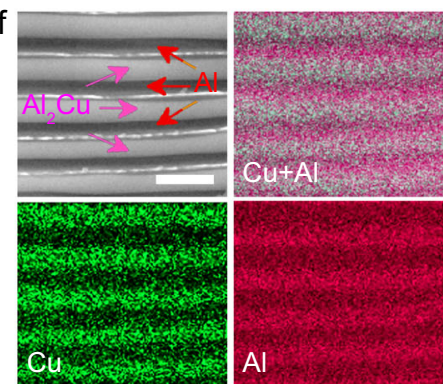
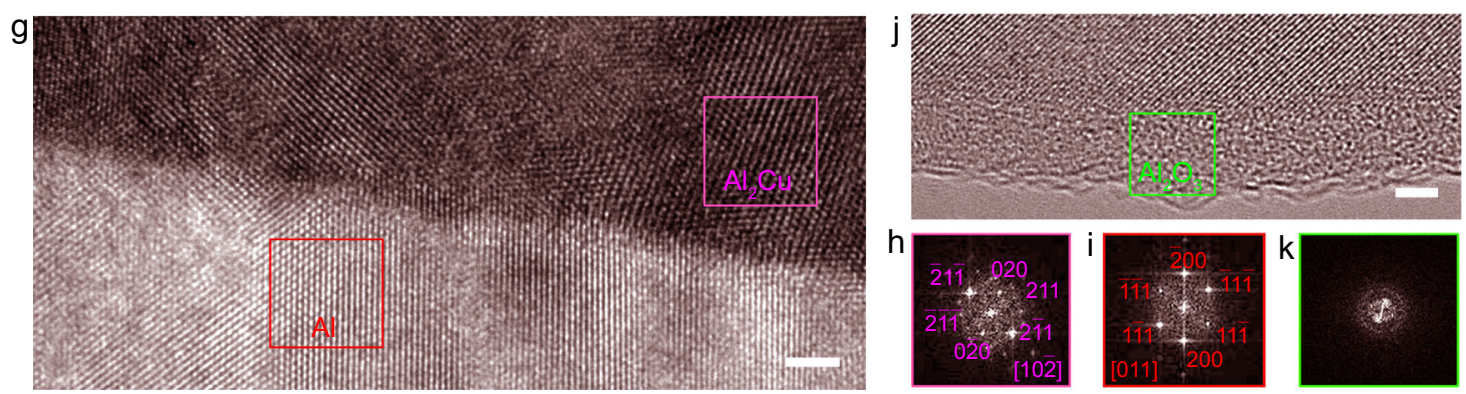

Fig. 1 Merits of Al metal anode and microstructure characterizations of eutectic Al-Cu alloys. a Comparisons of electrochemical properties, cost, and abundance for $\mathrm{Al}, \mathrm{Zn}, \mathrm{K}, \mathrm{Na}$, and $\mathrm{Li}$. b Schematic illustrating the procedure to prepare lamella-nanostructured $\mathrm{E}-\mathrm{Al}_{82} \mathrm{Cu}_{18}$ alloy composed of alternating $\alpha$ - $\mathrm{Al}$ (gray) and intermetallic $\mathrm{Al}_{2} \mathrm{Cu}$ (dark yellow) lamellas. c Photograph of as-prepared $\mathrm{E}-\mathrm{Al}_{82} \mathrm{Cu}_{18}$ alloy sheets with dimensions of $\sim 13 \mathrm{~cm} \times \sim 1.5 \mathrm{~cm} \times \sim 400 \mu \mathrm{m}$. Scale bar, $1 \mathrm{~cm}$. $\mathbf{d}$ XRD patterns of $\mathrm{E}-\mathrm{Al}_{82} \mathrm{Cu}_{18}$ (pink line), intermetallic $\mathrm{Al}_{2} \mathrm{Cu}$ (blue line) and monometallic $\mathrm{Al}$ (green line) electrode foils. The line patterns show reference cards 04-0787 and 25-0012 for face-centered cubic $\mathrm{Al}$ (yellow lines) and body-centered tetragonal $\mathrm{Al}_{2} \mathrm{Cu}$ (blue lines) according to JCPDS, respectively. e Representative optical micrograph of lamella-nanostructured $\mathrm{E}-\mathrm{Al}_{82} \mathrm{Cu}_{18}$ alloy with an interlamellar spacing of $420 \mathrm{~nm}$. Scale bar, $5 \mu \mathrm{m}$. f SEM backscattered electron image of $\mathrm{E}-\mathrm{Al}_{82} \mathrm{Cu}_{18}$ with different contrasts corresponding to $\alpha$-Al and intermetallic $\mathrm{Al}_{2} \mathrm{Cu}$ lamellas, as well as the corresponding EDS elemental mapping of $\mathrm{Cu}$ (in green) and $\mathrm{Al}$ (in red). Scale bar, $1 \mu \mathrm{m}$. $\mathbf{g} \mathrm{HRTEM}$ image of E- $\mathrm{Al}_{82} \mathrm{Cu}_{18}$ at $\mathrm{Al}_{2} \mathrm{Cu} / \mathrm{Al}$ interfacial region. Scale bar, $2 \mathrm{~nm}$. $\mathbf{h}$, i FFT patterns of selected red and pink boxes in intermetallic $\mathrm{Al}_{2} \mathrm{Cu}(\mathbf{h})$ and metallic $\mathrm{Al}(\mathbf{i})$ phases. $\mathbf{j} \mathrm{HRTEM}$ image of $\mathrm{Al} \mathrm{Al}_{2} \mathrm{O}_{3}$ interfacial region. Scale bar, $2 \mathrm{~nm}$. $\mathbf{k}$ FFT patterns of the selected area in amorphous $\mathrm{Al}_{2} \mathrm{O}_{3}$ layer in $\mathbf{j}$.

measurements are carried out in symmetric cell configuration using $2 \mathrm{M} \mathrm{Al}(\mathrm{OTF})_{3}$ aqueous electrolytes with various oxygen concentrations $\left(C_{\mathrm{O} 2}\right)$, which are adjusted by purging $\mathrm{O}_{2}$ or $\mathrm{N}_{2}$ for different time (Supplementary Table 2). Figure 2a shows a representative voltage profile of symmetric $\mathrm{E}-\mathrm{Al}_{82} \mathrm{Cu}_{18}$ cell during the $\mathrm{Al}$ stripping/plating at the current density of $0.5 \mathrm{~mA} \mathrm{~cm}^{-2}$, compared with those of symmetric $\mathrm{Al}_{2} \mathrm{Cu}$ and $\mathrm{Al}$ ones, in the $\mathrm{O}_{2}$ purged $\mathrm{Al}(\mathrm{OTF})_{3}$ aqueous electrolyte with $C_{\mathrm{O} 2}=13.6 \mathrm{mg} \mathrm{L}^{-1}$. The $\mathrm{E}-\mathrm{Al}_{82} \mathrm{Cu}_{18}$ symmetric cell exhibits relative flat and symmetric voltage plateaus at $\mathrm{Al}$ stripping/plating steps despite the hysteresis voltage gradually increasing to $\sim 180 \mathrm{mV}$ from the initial $150 \mathrm{mV}$ probably due to the continual formation of passivating oxide in such high-oxygen-concentration electrolyte (Supplementary Fig. 3a). This is in sharp contrast with the monometallic Al symmetric cell, of which the unstable overpotential runs up to as high as $\sim 2000-3000$ $\mathrm{mV}$ due to side reactions such as hydrogen evolution reaction and Al oxidation reaction (Fig. 2a and Supplementary Fig. 3b) $)^{11,14}$. While for the $\mathrm{Al}_{2} \mathrm{Cu}$ symmetric cell, it takes initial high overpotential of $\sim 400 \mathrm{mV}$ to strip $\mathrm{Al}$ from thermodynamically stable intermetallic $\mathrm{Al}_{2} \mathrm{Cu}$ phase. As the stripped $\mathrm{Al}$ fully takes part in the subsequent stripping/plating cycles, the overpotential gradually decreases to $\sim 195 \mathrm{mV}$ (Fig. 2a and Supplementary Fig. 3c), which is comparable to the value of $\mathrm{E}-\mathrm{Al}_{82} \mathrm{Cu}_{18}$ symmetric cell because of the formation of additional $\mathrm{Al} / \mathrm{Al}_{2} \mathrm{Cu}$ galvanic couples ${ }^{36,37,42}$.

While in the $\mathrm{Al}(\mathrm{OTF})_{3}$ aqueous electrolyte with a low oxygen concentration, these Al-based electrodes have their surface oxidation to be alleviated for improved Al stripping/plating (Supplementary Fig. 3a-c). As shown in Supplementary Fig. 3d, the overpotentials of these Al-based symmetric cells evidently decrease as the $C_{\mathrm{O} 2}$ is reduced to $0.13 \mathrm{mg} \mathrm{L}^{-1}$. Figure $2 \mathrm{~b}$ compares the initial voltage profiles of $\mathrm{E}-\mathrm{Al}_{82} \mathrm{Cu}_{18}, \mathrm{Al}_{2} \mathrm{Cu}$, and $\mathrm{Al}$ symmetric cells during the Al stripping/plating at $0.5 \mathrm{~mA} \mathrm{~cm}^{-2}$, in the $\mathrm{N}_{2}$ purged $\mathrm{Al}(\mathrm{OTF})_{3}$ aqueous electrolyte with $C_{\mathrm{O} 2}=0.13 \mathrm{mg} \mathrm{L}^{-1}$. As a consequence of notably suppressing the production of additional oxide, the $\mathrm{E}-\mathrm{Al}_{82} \mathrm{Cu}_{18}$ symmetric cell has the stable voltage plateaus of as low as $\sim 53 \mathrm{mV}$, only one sixth of the initial 

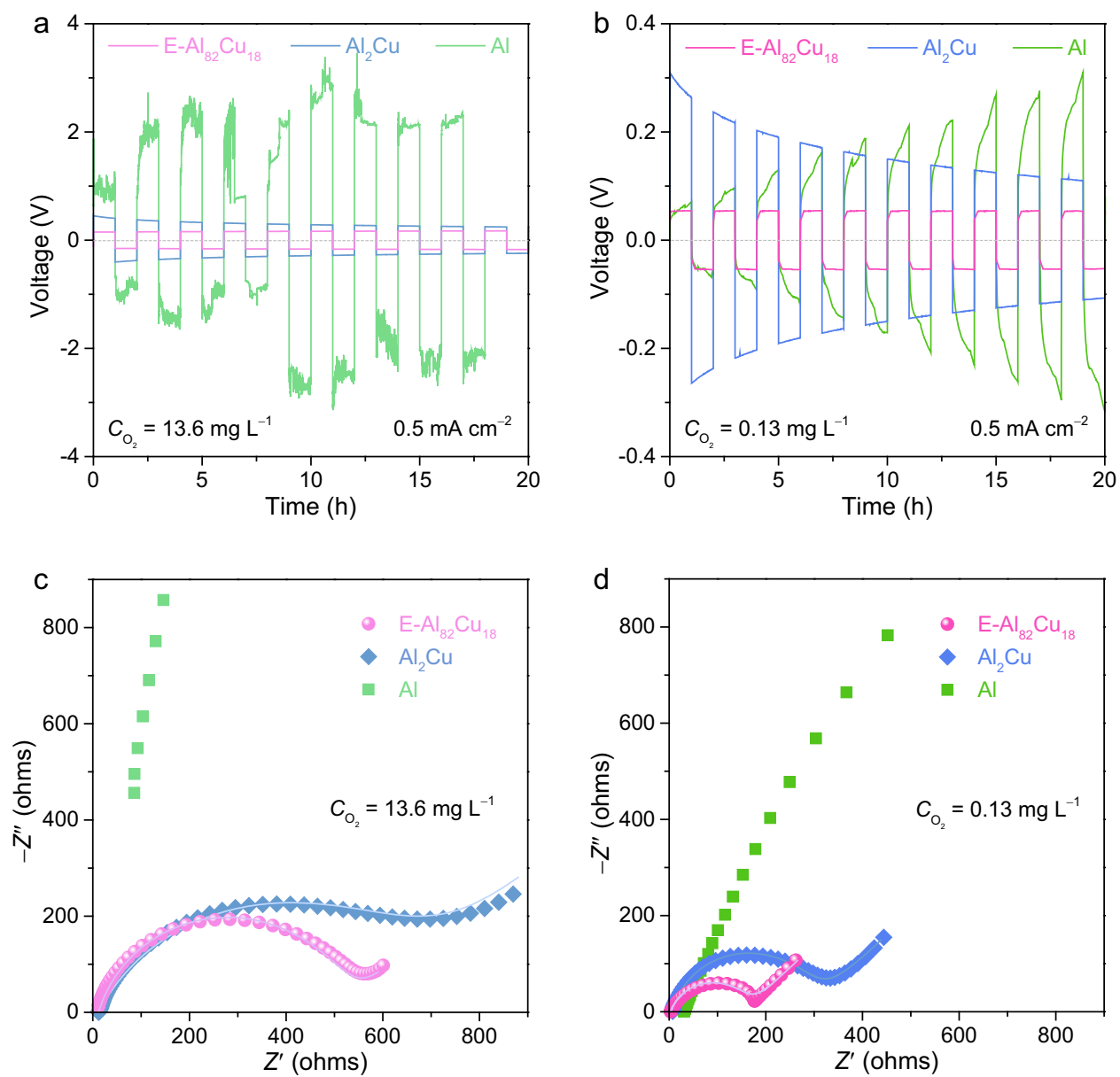

Fig. 2 Dependence of Al plating/stripping behaviors of eutectic Al-Cu alloys on oxygen concentrations. $\mathbf{a}$, $\mathbf{b}$ Al stripping/plating voltage profiles of $\mathrm{E}-\mathrm{Al}_{82} \mathrm{Cu}_{18}$ (pink line), $\mathrm{Al}_{2} \mathrm{Cu}$ (blue line), and pure $\mathrm{Al}$ (green line) electrodes in their as-assembled symmetric cells in $2 \mathrm{M} \mathrm{Al(OTF)}{ }_{3}$ aqueous electrolyte with $\mathrm{C}_{\mathrm{O} 2}=13.6$ (a) and $0.13 \mathrm{mg} \mathrm{L}^{-1}(\mathbf{b})$, which are purged by $\mathrm{O}_{2}$ and $\mathrm{N}_{2}$ for $2 \mathrm{~h}$, respectively. Current density: $0.5 \mathrm{~mA} \mathrm{~cm}^{-2}$. c, d EIS spectra of asassembled $\mathrm{E}-\mathrm{Al}_{82} \mathrm{Cu}_{18}, \mathrm{Al}_{2} \mathrm{Cu}$, and pure $\mathrm{Al}$ symmetric cells in $2 \mathrm{M} \mathrm{AI}(\mathrm{OTF})_{3}$ aqueous electrolyte with $\mathrm{C}_{\mathrm{O} 2}=13.6$ (c) and $0.13 \mathrm{mg} \mathrm{\textrm {L } ^ { - 1 }}$ (d). The symbols are the raw data of $\mathrm{E}-\mathrm{Al}_{82} \mathrm{Cu}_{18}$ (pink spheres), $\mathrm{Al}_{2} \mathrm{Cu}$ (blue diamonds), and pure $\mathrm{Al}$ (green squares) symmetric cells while the lines represent the fit data of $\mathrm{E}-\mathrm{Al}_{82} \mathrm{Cu}_{18}$ (pink line) and $\mathrm{Al}_{2} \mathrm{Cu}$ (blue line).

overpotentials $(\sim 300 \mathrm{mV})$ that are taken to strip $\mathrm{Al}$ from the intermetallic $\mathrm{Al}_{2} \mathrm{Cu}$ matrix for subsequent $\mathrm{Al}$ stripping/plating cycling in the $\mathrm{Al}_{2} \mathrm{Cu}$ symmetric cells. The less polarization of $\mathrm{E}-\mathrm{Al}_{82} \mathrm{Cu}_{18}$ cell is probably due to the lamellar nanostructure of $\mathrm{E}-\mathrm{Al}_{82} \mathrm{Cu}_{18}$ electrode, in which the constituent metallic $\alpha$ - $\mathrm{Al}$ and intermetallic $\mathrm{Al}_{2} \mathrm{Cu}$ lamellas play distinct roles in the $\mathrm{Al}$ stripping/plating cycles. By virtue of their different corrosion potentials ${ }^{36,37,42}$, the less-noble $\alpha$-Al thermodynamically prefers to work as the electroactive material to supply $\mathrm{Al}^{3+}$ charge carriers, and the more-noble $\mathrm{Al}_{2} \mathrm{Cu}$ pairs with the constituent $\alpha-\mathrm{Al}$ to form localized galvanic couples to trigger the $\mathrm{Al}$ stripping and serves as $2 \mathrm{D}$ nanopattern to guide the subsequent $\mathrm{Al}$ plating. No matter in which electrolyte with the $C_{\mathrm{O} 2}$ from 13.6 to $0.13 \mathrm{mg} \mathrm{L}^{-1}$, the lamellar nanostructure improves the $\mathrm{Al}$ stripping/plating behaviors of $\mathrm{E}-\mathrm{Al}_{82} \mathrm{Cu}_{18}$ (Supplementary Fig. 3a), compared with the monometallic $\mathrm{Al}$ that as a hostless electrode undergoes an increasing polarization process due to uncontrollable Al stripping/plating and unavoidable hydrogen evolution and $\mathrm{Al}$ oxidation reactions (Supplementary Fig. 3b) ${ }^{11,23}$. Their different $\mathrm{Al}$ stripping/plating behaviors are further investigated by using cyclic voltammetry $(\mathrm{CV})$ in the $\mathrm{N}_{2}$-purged $\mathrm{Al}(\mathrm{OTF})_{3}$ aqueous electrolyte with $C_{\mathrm{O} 2}=0.13 \mathrm{mg} \mathrm{L}^{-1}$, where the $\mathrm{E}-\mathrm{Al}_{82} \mathrm{Cu}_{18}, \mathrm{Al}_{2} \mathrm{Cu}$, and $\mathrm{Al}$ materials are used as the working and counter electrodes and the $\mathrm{Al}$ wire as the reference electrode in a three-electrode cell configuration. As shown in Supplementary Fig. 4 , the $\mathrm{E}-\mathrm{Al}_{82} \mathrm{Cu}_{18}$ electrode exhibits improved symmetric Al stripping/plating behaviors, with an onset potential of as low as $0 \mathrm{~V}$ versus $\mathrm{Al} /$ $\mathrm{Al}^{3+}$ and an improved current density compared to the other Albased electrodes. This is in sharp contrast to the intermetallic $\mathrm{Al}_{2} \mathrm{Cu}$ with strong $\mathrm{Cu}-\mathrm{Al}$ covalent bonds and the monometallic $\mathrm{Al}$ with native oxide layer, which have their onset potentials of $\mathrm{Al}$ stripping to reach $\sim 96$ and $\sim 172 \mathrm{mV}$, respectively, along the low current densities. The $\mathrm{Al} / \mathrm{Al}_{2} \mathrm{Cu}$ galvanic couple enhanced $\mathrm{Al}$ stripping/plating kinetics is also demonstrated by electrochemical impedance spectroscopy (EIS) measurements of symmetric E- $\mathrm{Al}_{82} \mathrm{Cu}_{18}, \mathrm{Al}_{2} \mathrm{Cu}$, and $\mathrm{Al}$ cells (Supplementary Fig. 5a-c). Figure $2 \mathrm{c}, \mathrm{d}$ show the representative Nyquist plots, comparing the EIS spectra of all Al-based symmetric cells in the $\mathrm{O}_{2^{-}}$and $\mathrm{N}_{2^{-}}$ purged $\mathrm{Al}(\mathrm{OTF})_{3}$ aqueous electrolytes with $\mathrm{C}_{\mathrm{O} 2}=13.6$ and $0.13 \mathrm{mg} \mathrm{L}^{-1}$, respectively. Therein, the $\mathrm{E}^{-} \mathrm{Al}_{82} \mathrm{Cu}_{18}$ symmetric cells display characteristic semicircles in the high- and middlefrequency range and inclined lines at the low frequencies, in contrast to those of the $\mathrm{Al}_{2} \mathrm{Cu}$ and $\mathrm{Al}$ ones with much larger diameters of semicircles. At high frequencies, the intersection point on the real axis represents the intrinsic resistance of both electrolyte and electrode $\left(R_{\mathrm{I}}\right)$. In the middle-frequency range, the diameter of the semicircle corresponds to the parallel connection of the charge transfer resistance $\left(R_{\mathrm{CT}}\right)$ of $\mathrm{Al}$ stripping/plating and 
the constant phase element (CPE). The slope of the inclined line at low frequencies is the Warburg resistance $\left(Z_{\mathrm{w}}\right)$. Based on these general descriptors in the equivalent circuit (Supplementary Fig. 5d), the EIS spectra are analyzed using the complex nonlinear least-squares fitting method. Supplementary Fig. 6a, b compare the $R_{\mathrm{I}}$ and $R_{\mathrm{CT}}$ values of all Al-based electrodes in the $\mathrm{Al}(\mathrm{OTF})_{3}$ aqueous electrolytes with different $C_{\mathrm{O} 2}$, where the $\mathrm{E}-\mathrm{Al}_{82} \mathrm{Cu}_{18}$ always has the lowest $R_{\mathrm{I}}$ and $R_{\mathrm{CT}}$ values. At $C_{\mathrm{O} 2}=0.13 \mathrm{mg} \mathrm{L}^{-1}$, the $R_{\mathrm{I}}$ of $\mathrm{E}-\mathrm{Al}_{82} \mathrm{Cu}_{18}$ electrode is as low as $\sim 3 \Omega$ because there forms an ultrathin oxide layer to facilitate the $\mathrm{Al}$ stripping/plating. Triggered by the periodical $\mathrm{Al} / \mathrm{Al}_{2} \mathrm{Cu}$ galvanic couples, the E- $\mathrm{Al}_{82} \mathrm{Cu}_{18}$ electrode has the $R_{\mathrm{CT}}$ of $\sim 160 \Omega$, more than twentyfold lower than that of the monometallic $\mathrm{Al}$ with a thicker passivating oxide layer $(\sim 3880 \Omega)$ (Supplementary Table 3).

To identify the specific roles of $\alpha-\mathrm{Al}$ and $\mathrm{Al}_{2} \mathrm{Cu}$ nanolamellas in the $\mathrm{E}-\mathrm{Al}_{82} \mathrm{Cu}_{18}$ electrodes, ex-situ SEM-EDS elemental mapping characterization is conducted after deep $\mathrm{Al}$ stripping and plating at $1 \mathrm{~mA} \mathrm{~cm}^{-2}$ for $10 \mathrm{~h}$ in the $\mathrm{Al}(\mathrm{OTF})_{3}$ aqueous electrolyte with $C_{\mathrm{O} 2}=0.13 \mathrm{mg} \mathrm{L}^{-1}$ (Fig. 3a). As shown in a typical SEM backscattered electron image of the Al-stripped $\mathrm{E}-\mathrm{Al}_{82} \mathrm{Cu}_{18}$ electrode (left inset of Fig. 3a), the constituent a-Al lamellas as electroactive materials selectively dissolve during the $\mathrm{Al}$ stripping process while the intermetallic $\mathrm{Al}_{2} \mathrm{Cu}$ ones are left to form a lamella-nanostructured $2 \mathrm{D}$ pattern. This is also illustrated by its corresponding SEM-EDS elemental mapping of $\mathrm{Al}$ and $\mathrm{Cu}$ (left insets of Fig. 3a), wherein the $\mathrm{Al}$ atoms distribute along the $\mathrm{Cu}$-rich $\mathrm{Al}_{2} \mathrm{Cu}$ lamellas. During the subsequent $\mathrm{Al}$ electroplating process, the $\mathrm{Al}$ is incorporated into the stripped $\mathrm{E}-\mathrm{Al}_{82} \mathrm{Cu}_{18}$ along the in-situ formed structural bidimentional $\mathrm{Al}_{2} \mathrm{Cu}$ nanopatterns. As shown in the SEM-EDS elemental mapping images of Al-stripped and -plated $\mathrm{E}-\mathrm{Al}_{82} \mathrm{Cu}_{18}$ (right insets of Fig. 3a), the electrodeposited $\mathrm{Al}$ atoms uniformly distribute in the channels sandwiched between the $\mathrm{Al}_{2} \mathrm{Cu}$ lamellas, the same as the pristine $\mathrm{E}-\mathrm{Al}_{82} \mathrm{Cu}_{18}$ (Fig. 1e). According to the voltage profiles of $\mathrm{Al}$ stripping/ plating processes, the energy efficiency (EE) is evaluated to be $\sim 99.4 \%$ in terms of the equation $\mathrm{EE}=\int I V_{\text {stripping }}(t) \mathrm{d} t / \int I V_{\text {plating }}(t) \mathrm{d} t$, indicating the high $\mathrm{Al}$ reversibility of $\mathrm{E}-\mathrm{Al}_{82} \mathrm{Cu}_{18}$ electrode. Here $I$ is the current density, $V_{\text {stripping }}(t)$ and $V_{\text {plating }}(t)$ are the stripping and plating voltages at the time $(t)$.

Owing to the lamella-nanostructured $\mathrm{Al}_{2} \mathrm{Cu}$ pattern that enhances the $\mathrm{Al}$ stripping/plating kinetics of the constituent $\alpha$-Al lamellas, the symmetric $\mathrm{E}-\mathrm{Al}_{82} \mathrm{Cu}_{18}$ cell exhibits a better rate performance in the aqueous $\mathrm{Al}(\mathrm{OTF})_{3}$ electrolyte with $C_{\mathrm{O} 2}=0.13 \mathrm{mg} \mathrm{L}^{-1}$. As shown in Fig. 3 b, the $\mathrm{E}-\mathrm{Al}_{82} \mathrm{Cu}_{18}$ symmetric cell has a steadily increasing hysteresis of $\sim 31, \sim 56$, and $\sim 103 \mathrm{mV}$ when the current density is increased from 0.5 to $1.0,1.5$, and $2.5 \mathrm{~mA} \mathrm{~cm}^{-2}$. These hysteresis voltages are much lower than the values of the symmetric cells based on intermetallic $\mathrm{Al}_{2} \mathrm{Cu}(\sim 51, \sim 95$, and $\sim 192 \mathrm{mV})$ and monometallic $\mathrm{Al}(\sim 1750, \sim 2990$, and $\sim 4530 \mathrm{mV})$ electrodes. Figure 3c compares the $\mathrm{Al}$ stripping/plating cycling stabilities of all Al-based symmetric cells. Obviously, the voltage profile of $\mathrm{E}-\mathrm{Al}_{82} \mathrm{Cu}_{18}$ symmetric cell does not display evident fluctuation in the long-term cycling at $0.5 \mathrm{~mA} \mathrm{~cm}^{-2}$ for more than $2000 \mathrm{~h}$, except for the slight reduction in overpotential from initial $\sim 53 \mathrm{mV}$ to final $\sim 37 \mathrm{mV}$ probably due to the formation of less and less oxide (right inset of Fig. $3 \mathrm{c}$ ) and the negligible hydrogen evolution (Supplementary Fig. 7a). This is in contrast with those of $\mathrm{Al}_{2} \mathrm{Cu}$ and $\mathrm{Al}$ symmetric cells with much larger voltage hysteresis and fluctuation at $180 \mathrm{~h}$ and $26 \mathrm{~h}$, respectively (Fig. 3c). When extending the cycling time, there take place severe side reactions of hydrogen evolution and $\mathrm{Al}$ oxidation along with the $\mathrm{Al}$ stripping/plating processes, especially in the monometallic $\mathrm{Al}$ symmetric cell (left inset of Fig. $3 \mathrm{c}$ and Supplementary Fig. 7b). The hydrogen generation is identified by in-situ gas chromatography (Supplementary Fig. 7c). The hydrogen production increases the $\mathrm{pH}$ value of electrolytes to facilitate the oxidation of $\mathrm{Al}$ metal and thus aggravate side reactions ${ }^{11,43}$, which leads to cell case damage and electrolyte leak (Supplementary Fig. 8). As attested by the more intensive Raman bands and the change of chemical states of Al in XPS spectra (Supplementary Figs. 9 and 10), there indeed produces additional $\mathrm{Al}_{2} \mathrm{O}_{3}$ on the monometallic $\mathrm{Al}$ electrode after 40 stripping/plating cycles. While in the $\mathrm{E}-\mathrm{Al}_{82} \mathrm{Cu}_{18}$ symmetric cell, the surface oxide of $\mathrm{E}-\mathrm{Al}_{82} \mathrm{Cu}_{18}$ electrode is probably below the detection limit for the Raman spectroscopy measurements (Supplementary Figs. 11 and 12), which enables highly reversible $\mathrm{Al}$ stripping/plating at low overpotential. Furthermore, there does not observe any bubbles on the $\mathrm{E}-\mathrm{Al}_{82} \mathrm{Cu}_{18}$ electrodes during the $\mathrm{Al}$ stripping/plating processes (Supplementary Fig. 7b). The improved

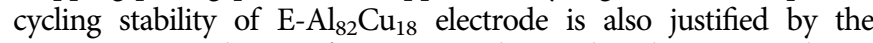
unconspicuous change of EIS spectra during the Al stripping/plating processes (Fig. 3d). Relative to the initial values of $R_{\mathrm{I}}$ and $R_{\mathrm{CT}}$, they only increase by $\sim 2$ and $\sim 20 \Omega$ after 120 cycles, respectively, much lower than those of intermetallic $\mathrm{Al}_{2} \mathrm{Cu}$ electrodes $(\sim 8$ and $\sim 290 \Omega$ ) (Fig. 3e and Supplementary Table 4). While the monometallic Al symmetric cell has its $R_{\mathrm{I}}$ and $R_{\mathrm{CT}}$ values to increase to $\sim 36$ and $\sim 8855 \Omega$ only after 12 cycles (Fig. 3 f and Supplementary Table 4 ). By virtue of the high reversibility of $\mathrm{Al}$ stripping/plating, the $\mathrm{E}-\mathrm{Al}_{82} \mathrm{Cu}_{18}$ electrode still keeps the initial lamella nanostructure even after more than 1000 cycles (2000 h) (Supplementary Fig. 13a), in stark contrast to the $\mathrm{Al}_{2} \mathrm{Cu}$ and $\mathrm{Al}$ electrodes that are performed for only 125 and 20 cycles of $\mathrm{Al}$ stripping/plating, respectively. As shown in Supplementary Fig. 13b, c, there appear a large number of cracks on $\mathrm{Al}_{2} \mathrm{Cu}$ and $\mathrm{Al}$ electrodes. All these electrochemical and structural features verify the effective $\mathrm{Al}$ stripping/plating behaviors of E- $\mathrm{Al}_{82} \mathrm{Cu}_{18}$ electrode because of its lamellar nanostructure of alternating intermetallic $\mathrm{Al}_{2} \mathrm{Cu}$ and $\alpha-\mathrm{Al}$ lamellas.

Electrochemical energy storage performances of Al-ion full cells. To develop $\mathrm{E}-\mathrm{Al}_{82} \mathrm{Cu}_{18}$-based AR-AMB full cells for practical use, a cathodic material of $\mathrm{Al}^{3+}$ pre-intercalated manganese oxide $\left(\mathrm{Al}_{x} \mathrm{MnO}_{2} \cdot n \mathrm{H}_{2} \mathrm{O}\right)$ is prepared by a modified hydrothermal method. Supplementary Figure 14a, b show low-magnification SEM and TEM images of as-prepared $\mathrm{Al}_{x} \mathrm{MnO}_{2} \cdot n \mathrm{H}_{2} \mathrm{O}$, displaying a hierarchical nanostructure consisting of nanosheets with thickness of $\sim 10 \mathrm{~nm}$. The HRTEM image of $\mathrm{Al}_{x} \mathrm{MnO}_{2} \cdot n \mathrm{H}_{2} \mathrm{O}$ nanosheets illustrates the nature of layered crystalline structure (inset of Supplementary Fig. 14b). According to the spectral features of the $\mathrm{Mn}-\mathrm{O}$ vibrations ${ }^{44,45}$, the characteristic Raman bands at 506,573, and $641 \mathrm{~cm}^{-1}$ unveil a birnessite-type structure (Supplementary Fig. 14c) ${ }^{46}$. This is further confirmed by the obvious diffraction peaks in the XRD patterns of $\mathrm{Al}_{x} \mathrm{MnO}_{2} \cdot n \mathrm{H}_{2} \mathrm{O}$ at $2 \theta=10.9^{\circ}, 25.2^{\circ}, 36.7^{\circ}, 65.9^{\circ}$, which correspond to the 001 , 002, 110, and 020 reflections of birnessite (JCPDS 43-1456) (Supplementary Fig. 14d). The diffraction peaks deviating from their corresponding line patterns indicates the pre-intercalation of hydrated $\mathrm{Al}^{3+}$ cation. In terms of the 001 diffraction peak position, the interlayer spacing of $\mathrm{Al}_{x} \mathrm{MnO}_{2} \cdot n \mathrm{H}_{2} \mathrm{O}$ nanosheets is evaluated to be $0.811 \mathrm{~nm}$, in agreement with the observation in the HRTEM image (inset of Supplementary Fig. 14b). The XPS survey spectrum attests to the presence of $\mathrm{Al}, \mathrm{Mn}$, and $\mathrm{O}$ atoms in the as-prepared $\mathrm{Al}_{x} \mathrm{MnO}_{2} \cdot n \mathrm{H}_{2} \mathrm{O}$ nanosheets (Supplementary Fig. 15a), where the $x$ value is evaluated to be $\sim 0.12$ according to inductively coupled plasma optical emission spectroscopy (ICPOES) analysis (Supplementary Table 5). In high-resolution Al $2 p$ XPS spectrum (Supplementary Fig. 15b), the characteristic peak at the binding energy of $75.0 \mathrm{eV}$ is attributed to the preintercalated $\mathrm{Al}^{3+}$ cations that are engaged into the $\mathrm{MnO}_{6}$ sheets to adjust the chemical states of $\mathrm{Mn}^{3+}$ and $\mathrm{Mn}^{4+}$ (Supplementary Fig. 15c) ${ }^{12,15}$. O 1s XPS analysis demonstrates that there mainly exist three oxygen-containing species, i.e., the $\mathrm{O}_{2}{ }^{-}$in $\mathrm{MnO}_{6}$ lattice, the $\mathrm{OH}^{-}$and the $\mathrm{H}_{2} \mathrm{O}$, to correspond to the peaks at the binding energies of 529.8, 530.9, and $533.0 \mathrm{eV}$ (Supplementary 

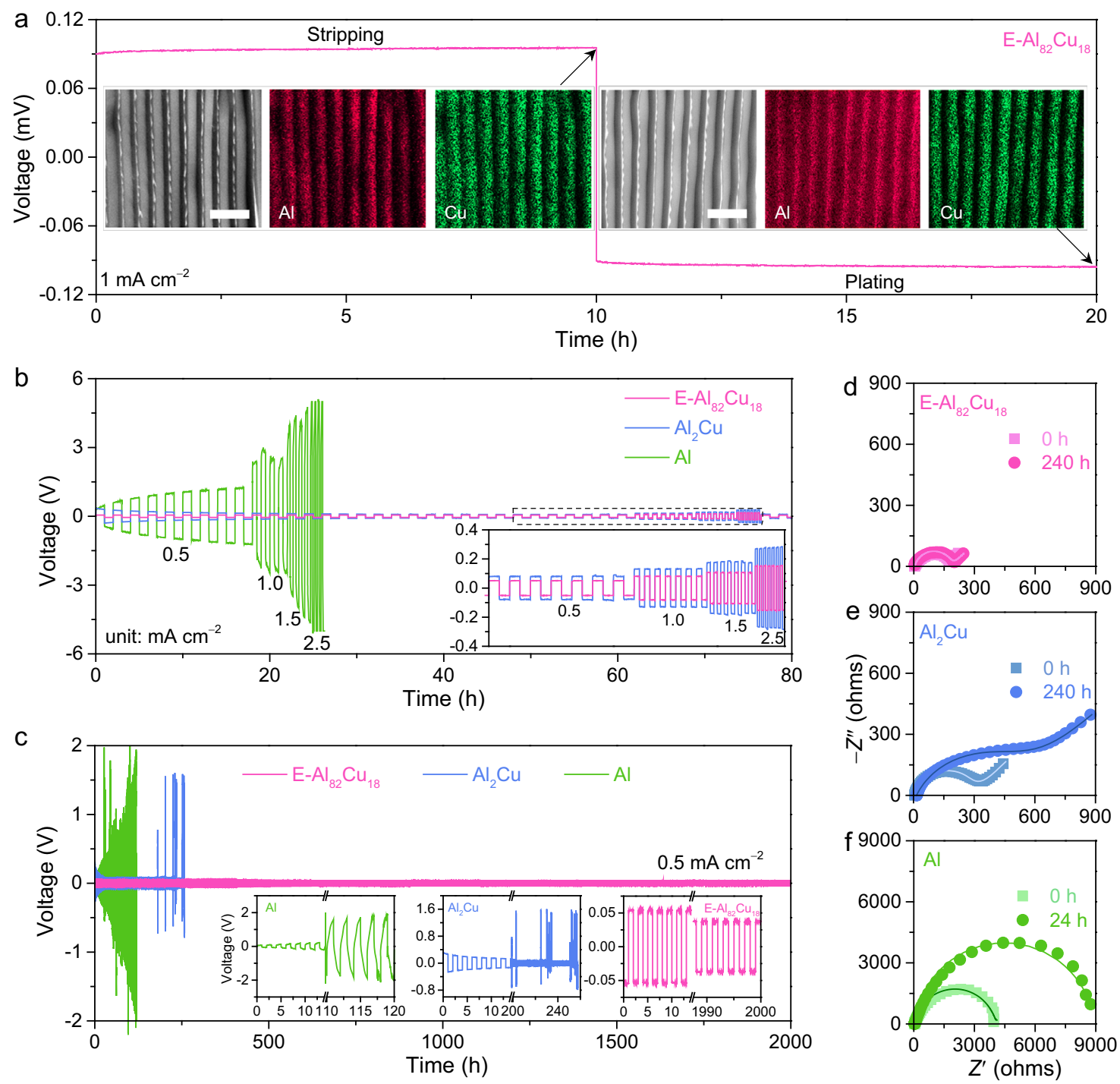

Fig. 3 Electrochemical characterizations of the Al-based symmetric cells. a Typical stripping/plating voltage profile (pink line) of $\mathrm{E}-\mathrm{Al}_{82} \mathrm{Cu}_{18} \mathrm{symmetric}$ cells in $2 \mathrm{M} \mathrm{AI}(\mathrm{OTF})_{3}$ aqueous electrolyte with $\mathrm{C}_{\mathrm{O} 2}=0.13 \mathrm{mg} \mathrm{L}^{-1}$. Current density: $1 \mathrm{~mA} \mathrm{~cm}^{-2}$. Insets: representative SEM images and the corresponding SEM-EDS elemental mappings of $\mathrm{Al}$ (in red) and $\mathrm{Cu}$ (in green) for the $\mathrm{E}-\mathrm{Al}_{82} \mathrm{Cu}_{18}$ electrode after $\mathrm{Al}$ stripping (left) and then $\mathrm{Al}$ plating processes (right). Scale bars, $1 \mu \mathrm{m}$. $\mathbf{b}$ Comparison of rate performance for symmetric cells of $\mathrm{E}-\mathrm{Al}_{82} \mathrm{Cu}_{18}$ (pink line), $\mathrm{Al}_{2} \mathrm{Cu}$ (blue line), and $\mathrm{Al}$ (green line) electrodes in $2 \mathrm{M}$ $\mathrm{Al}(\mathrm{OTF})_{3}$ aqueous electrolyte with $\mathrm{C}_{\mathrm{O} 2}=0.13 \mathrm{mg} \mathrm{L}^{-1}$ at various current densities of $0.5,1.0,1.5,2.5 \mathrm{~mA} \mathrm{~cm}^{-2}$. Inset: enlarged voltage-time profiles comparing the stripping/plating behaviors of $\mathrm{E}-\mathrm{Al}_{82} \mathrm{Cu}_{18}$ (pink line) and $\mathrm{Al}_{2} \mathrm{Cu}$ (blue line) electrodes at different current densities. $\mathbf{c}$ Long-term cycling stability of $\mathrm{Al}$ stripping/plating for symmetric cells based on $\mathrm{E}-\mathrm{Al}_{82} \mathrm{Cu}_{18}$ (pink line), $\mathrm{Al}_{2} \mathrm{Cu}$ (blue line), and $\mathrm{Al}$ (green line) electrodes at $0.5 \mathrm{~mA} \mathrm{~cm}-2$ in $2 \mathrm{M}$ $\mathrm{Al}(\mathrm{OTF})_{3}$ aqueous electrolyte with $\mathrm{C}_{\mathrm{O} 2}=0.13 \mathrm{mg} \mathrm{L}^{-1}$. Inset: voltage evolutions for $\mathrm{Al}$ (left), $\mathrm{Al}_{2} \mathrm{Cu}$ (middle), and $\mathrm{E}-\mathrm{Al}_{82} \mathrm{Cu}_{18}$ (right). d-f EIS spectra of $\mathrm{E}-\mathrm{Al}_{82} \mathrm{Cu}_{18}(\mathbf{d}), \mathrm{Al}_{2} \mathrm{Cu}(\mathbf{e})$, and $\mathrm{Al}(\mathbf{f})$ symmetric cells before and after the stripping/plating cycling measurements for $240 \mathrm{~h}, 240 \mathrm{~h}$, and $24 \mathrm{~h}$, respectively, in $2 \mathrm{M} \mathrm{Al}(\mathrm{OTF})_{3}$ aqueous electrolyte with $\mathrm{C}_{\mathrm{O} 2}=0.13 \mathrm{mg} \mathrm{L}^{-1}$. The square and circle symbols are the raw data of $\mathrm{E}-\mathrm{Al}_{82} \mathrm{Cu}_{18}(\mathbf{d}), \mathrm{Al}_{2} \mathrm{Cu}(\mathbf{e})$, and $\mathrm{Al}(\mathbf{f})$ symmetric cells before and after Al stripping/plating for $240 \mathrm{~h}$, respectively, in which the lines represent their fit data.

Fig. 15d $)^{7,47}$. Therein, the latter is assigned to both crystal water and constitution water, which are identified by thermogravimetric analysis (TGA) at the temperature below $510^{\circ} \mathrm{C}$. As shown by the TGA profile (Supplementary Fig. 15e), the weight loss below $120^{\circ} \mathrm{C}$ is attributed to the removal of the crystal water ${ }^{48}$. When increasing temperature from $120^{\circ} \mathrm{C}$ to $510^{\circ} \mathrm{C}$, the corresponding weight loss is ascribed to the constitutional water due to the formation of hydrated $\mathrm{Al}^{3+}$ with a high enthalpy ${ }^{49}$.

Figure 4a shows representative cyclic voltammetry $(\mathrm{CV})$ curves of full AR-AMB cells that are assembled with the $\mathrm{E}-\mathrm{Al}_{82} \mathrm{Cu}_{18}$ alloy or monometallic $\mathrm{Al}$ anode and the $\mathrm{Al}_{x} \mathrm{MnO}_{2} \cdot n \mathrm{H}_{2} \mathrm{O}$ cathode, i.e., $\mathrm{E}-\mathrm{Al}_{82} \mathrm{Cu}_{18}|| \mathrm{Al}_{x} \mathrm{MnO}_{2}$ or $\mathrm{Al}|| \mathrm{Al}_{x} \mathrm{MnO}_{2}$, in $2 \mathrm{M} \mathrm{Al}(\mathrm{OTF})_{3}$ aqueous electrolyte with $\mathrm{C}_{\mathrm{O} 2}=0.13 \mathrm{mg} \mathrm{L}^{-1}$. Though both $\mathrm{E}-\mathrm{Al}_{82} \mathrm{Cu}_{18}|| \mathrm{Al}_{x} \mathrm{MnO}_{2}$ and $\mathrm{Al} \| \mathrm{Al}_{x} \mathrm{MnO}_{2}$ AR-AMB cells have the same cathode material of $\mathrm{Al}_{x} \mathrm{MnO}_{2} \cdot n \mathrm{H}_{2} \mathrm{O}$ nanosheets, they exhibit distinct voltammetric behaviors due to their different anodes, i.e., the lamella-nanostructured $\mathrm{E}-\mathrm{Al}_{82} \mathrm{Cu}_{18}$ and the monometallic $\mathrm{Al}$, indicating the significance of Al-based anodes in determining electrochemical performance of full AR-AMB cells. By virtue of the improved $\mathrm{Al}$ stripping/plating properties of E- $\mathrm{Al}_{82} \mathrm{Cu}_{18}$ enabling a fast reaction kinetics of $\mathrm{Al}^{3+}$ intercalation/ deintercalation in the $\mathrm{Al}_{x} \mathrm{MnO}_{2} \cdot n \mathrm{H}_{2} \mathrm{O}$, the $\mathrm{E}-\mathrm{Al}_{82} \mathrm{Cu}_{18}|| \mathrm{Al}_{x} \mathrm{MnO}_{2}$ cell shows enhanced current density and positively shifted voltages of anodic/cathodic peaks relative to the $\mathrm{Al}|| \mathrm{Al}_{x} \mathrm{MnO}_{2}$. At the scan rate of $0.1 \mathrm{mV} \mathrm{s}^{-1}$, the anodic and cathodic peaks of $\mathrm{E}-\mathrm{Al}_{82} \mathrm{Cu}_{18}||$ $\mathrm{Al}_{x} \mathrm{MnO}_{2}$ can reach $\sim 1.647$ and $\sim 1.491 \mathrm{~V}$, respectively, with the voltage difference of $\sim 156 \mathrm{mV}$. Whereas the voltage difference of anodic and cathodic peaks increases to $\sim 673 \mathrm{mV}$ when increasing 

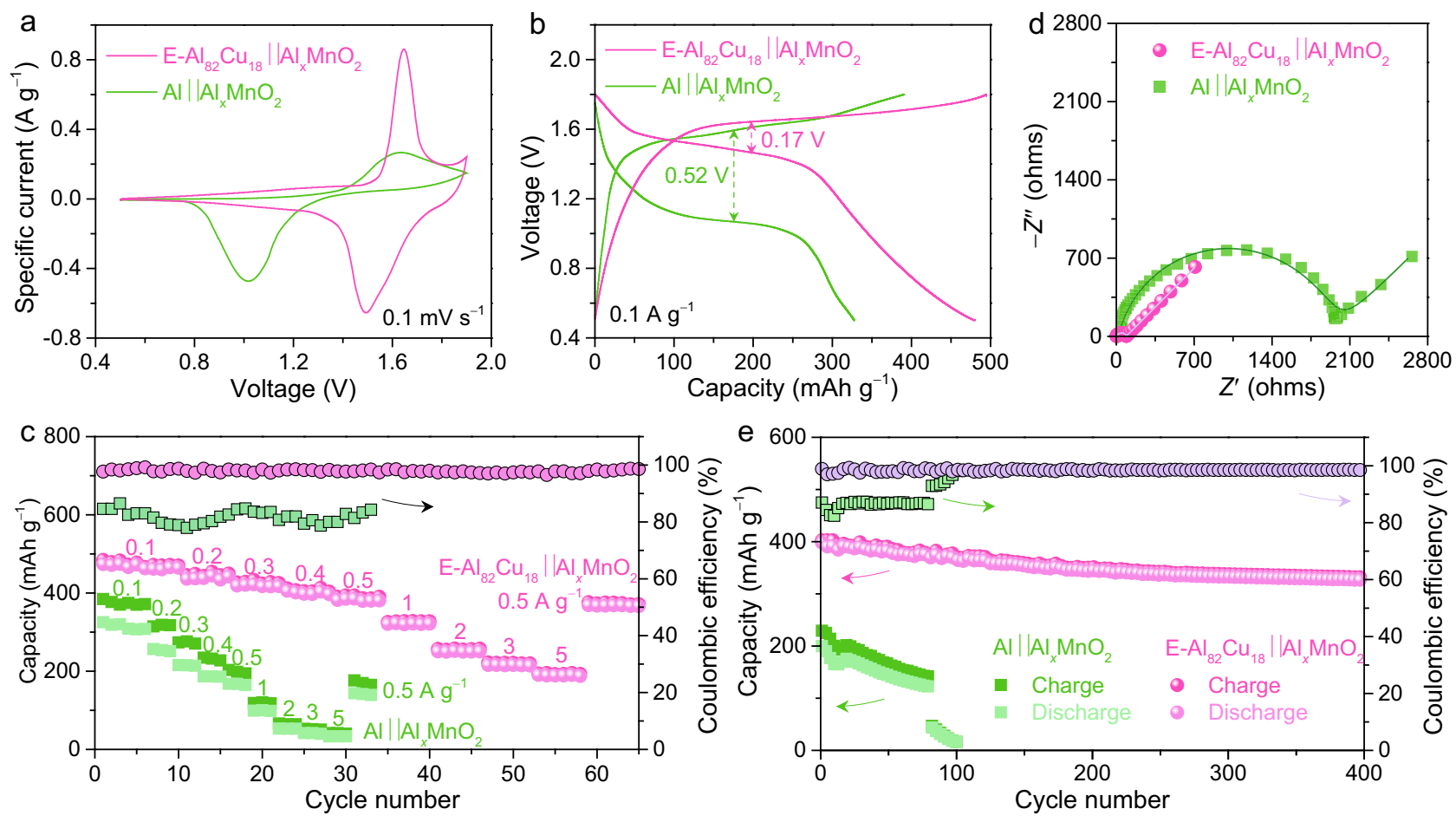

Fig. 4 Electrochemical characterizations of the aqueous Al-ion full cells. a Representative $C V$ curves for full $\mathrm{E}-\mathrm{Al}_{82} \mathrm{Cu}_{18}|| \mathrm{Al}_{x} \mathrm{MnO} \mathrm{O}_{2}(\mathrm{pink}$ line) and

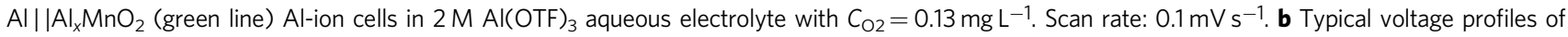
$\mathrm{E}-\mathrm{Al}_{82} \mathrm{Cu}_{18}|| \mathrm{Al}_{x} \mathrm{MnO}_{2}$ (pink line) and $\mathrm{Al}|| \mathrm{Al}_{x} \mathrm{MnO}_{2}$ (green line) cells at the specific current of $0.1 \mathrm{~A} \mathrm{~g}^{-1}$. c Comparison of rate performance and Coulombic efficiency for $\mathrm{E}-\mathrm{Al}_{82} \mathrm{Cu}_{18}|| \mathrm{Al}_{x} \mathrm{MnO}_{2}$ (pink spheres) and $\mathrm{Al}|| \mathrm{Al}_{x} \mathrm{MnO}_{2}$ cells (green squares), which are performed at various specific currents from 0.1 to $5 \mathrm{~A} \mathrm{~g}^{-1}$. d EIS spectra of $\mathrm{E}-\mathrm{Al}_{82} \mathrm{Cu}_{18}|| \mathrm{Al}_{x} \mathrm{MnO}_{2}$ and $\mathrm{Al} \| \mid \mathrm{Al}_{x} \mathrm{MnO}_{2}$ full cells. The pink sphere and green square symbols are the raw data of $\mathrm{E}-\mathrm{Al}_{82} \mathrm{Cu}_{18}|| \mathrm{Al} \mathrm{I}_{x} \mathrm{MnO}_{2}$ and Al ||$A I_{x} \mathrm{MnO}_{2}$ full cells while the light pink and dark green lines represent their fit data, respectively. e Capacity retentions and Coulombic efficiencies of $\mathrm{E}-\mathrm{Al}_{82} \mathrm{Cu}_{18}|| \mathrm{Al}_{x} \mathrm{MnO}_{2}$ (pink spheres) and $\mathrm{Al}|| \mathrm{Al}_{x} \mathrm{MnO}_{2}$ cells (green squares) in a long-term charge/discharge cycling measurement at $0.5 \mathrm{Ag}{ }^{-1}$.

the scan rate to $3 \mathrm{mV} \mathrm{s}^{-1}$ (Supplementary Fig. 16a), it is still much smaller than that of $\mathrm{Al} \| \mid \mathrm{Al}_{x} \mathrm{MnO}_{2}$ cell at the scan rate of $0.2 \mathrm{mV} \mathrm{s}^{-1}(\sim 863 \mathrm{mV})$ (Supplementary Fig. 16b). These observations indicate the improved rate capability of $\mathrm{E}-\mathrm{Al}_{82} \mathrm{Cu}_{18}||$ $\mathrm{Al}_{x} \mathrm{MnO}_{2}$ cell. As shown in Supplementary Fig. 16c, the $\mathrm{E}-\mathrm{Al}_{82} \mathrm{Cu}_{18}|| \mathrm{Al}_{x} \mathrm{MnO}_{2}$ cell can achieve a specific capacity of as high as $\sim 478 \mathrm{mAh} \mathrm{g}^{-1}$ (based on the loading mass of $\mathrm{Al}_{x} \mathrm{MnO}_{2}$ in the cathode) at $0.1 \mathrm{mV} \mathrm{s}^{-1}$ and retains $\sim 249 \mathrm{mAh} \mathrm{g}^{-1}$ at $3 \mathrm{mV} \mathrm{s}^{-1}$ (i.e., the discharge time of $467 \mathrm{~s}$ ), even comparable to that of $\mathrm{Al}||$ $\mathrm{Al}_{x} \mathrm{MnO}_{2}$ cell $\left(262 \mathrm{mAh} \mathrm{g}^{-1}\right)$ at $0.2 \mathrm{mV} \mathrm{s}^{-1}$ (7000 s).

Figure $4 \mathrm{~b}$ and Supplementary Fig. 17a, b show the representative voltage profiles for the galvanostatic charge and discharge of $\mathrm{E}-\mathrm{Al}_{82} \mathrm{Cu}_{18}|| \mathrm{Al}_{x} \mathrm{MnO}_{2}$ and $\mathrm{Al}|| \mathrm{Al}_{x} \mathrm{MnO}_{2} \mathrm{AR}-\mathrm{AMB}$ cells, with the voltage plateaus being consistent with their corresponding redox peaks in the $\mathrm{CV}$ curves due to the intercalation/deintercalation of $\mathrm{Al}^{3+}$ via $\mathrm{Al}_{x} \mathrm{MnO}_{2} \cdot n \mathrm{H}_{2} \mathrm{O}+3(y-x) e^{-}+(y-x) \mathrm{Al}^{3+}$ $\leftrightarrow \mathrm{Al}_{y} \mathrm{MnO}_{2} \cdot n \mathrm{H}_{2} \mathrm{O}$ (Fig. 4a and Supplementary Fig. 16a, b) ${ }^{12}$, which is demonstrated by XPS analysis of $\mathrm{Al}_{x} \mathrm{MnO}_{2}$ cathode after the discharge and charge (Supplementary Figs. 18 and 19). As shown in Supplementary Fig. 18a, b for the Mn $2 p$ and $\mathrm{Al} 2 p$ of the discharged $\mathrm{Al}_{y} \mathrm{MnO}_{2}$, the intercalation of $\mathrm{Al}^{3+}$ leads to the $y$ value of as high as 0.56 , accompanied by the change of chemical state of $\mathrm{Mn}$ from $\mathrm{Mn}^{3+}$ and $\mathrm{Mn}^{4+}$ to $\mathrm{Mn}^{2+}$. As for the charged $\mathrm{Al}_{x} \mathrm{MnO}_{2}$, the content of $\mathrm{Al}$ decreases to $x=\sim 11$ due to the deintercalation of $\mathrm{Al}^{3+}$, where the chemical state of $\mathrm{Mn}$ changes to $\mathrm{Mn}^{3+}$ and $\mathrm{Mn}^{4+}$ from $\mathrm{Mn}^{2+}$ (Supplementary Fig. 19a, b). In the charge or discharge state, the $\mathrm{F}$ and $\mathrm{S}$ contents are detected to be constant probably due to the physical adsorption of OTF ligands on the surface of $\mathrm{Al}_{x} \mathrm{MnO}_{2}$ (Supplementary Figs. 18d, e and 19d, e). Evidently, the use of $\mathrm{E}-\mathrm{Al}_{82} \mathrm{Cu}_{18}$ alloy anode enlists the $\mathrm{E}-\mathrm{Al}_{82} \mathrm{Cu}_{18}|| \mathrm{Al}_{x} \mathrm{MnO}_{2}$ cell to exhibit a higher discharge plateau and smaller voltage polarization, giving rise to a dramatically improved energy efficiency. As manifested by the charge/ discharge voltage difference $(\Delta E)$ at the specific current of $100 \mathrm{mAg}^{-1} \quad(\sim 0.2 \mathrm{C})^{50}$, the $\Delta E$ decreases to $0.17 \mathrm{~V}$ of $\mathrm{E}-\mathrm{Al}_{82} \mathrm{Cu}_{18}|| \mathrm{Al}_{x} \mathrm{MnO}_{2}$ from $0.52 \mathrm{~V}$ of $\mathrm{Al}|| \mathrm{Al}_{x} \mathrm{MnO}_{2}$. Furthermore, the discharge capacity of $\mathrm{E}-\mathrm{Al}_{82} \mathrm{Cu}_{18}|| \mathrm{Al}_{x} \mathrm{MnO}_{2}$ reaches as high as $\sim 480 \mathrm{mAh} \mathrm{g}^{-1}, \sim 1.5$-fold of the $\mathrm{Al}|| \mathrm{Al}_{x} \mathrm{MnO}_{2}$ $\left(\sim 328 \mathrm{mAh}^{-1}\right)$. Even as the rate increases to $10 \mathrm{C}$ (i.e., $5000 \mathrm{~mA} \mathrm{~g}^{-1}$ ), it still stores/delivers the capacities of $\sim 194 /$ $\sim 190 \mathrm{mAh}^{-1}$ in $6 \mathrm{~min}$ (Fig. 4c), with a high Coulombic efficiency of $\sim 98 \%$ (Supplementary Fig. 20). In comparison, the charge/discharge capacities of $\mathrm{Al}|| \mathrm{Al}_{x} \mathrm{MnO}_{2}$ decrease to 42 / $\sim 33 \mathrm{mAh} \mathrm{g}^{-1}$ (Fig. 4c), with a lower Coulombic efficiency of $\sim 78 \%$ (Supplementary Fig. 20). As a result, the $\mathrm{E}-\mathrm{Al}_{82} \mathrm{Cu}_{18}$ $\mathrm{Al}_{x} \mathrm{MnO}_{2}$ achieves the highest specific energy of $\sim 672 \mathrm{Wh} \mathrm{kg}^{-1}$ (energy density of $815 \mathrm{Wh} \mathrm{L}^{-1}$ based on the volume of cathode) at $100 \mathrm{~mA} \mathrm{~g}^{-1}$ and retains $\sim 212 \mathrm{Wh} \mathrm{kg}^{-1}$ at $5000 \mathrm{~mA} \mathrm{~g}^{-1}$ (Supplementary Fig. 21) ${ }^{51}$, comparable to representative LIBs (Supplementary Table 6). These electrochemical energy storage properties of $\mathrm{E}-\mathrm{Al}_{82} \mathrm{Cu}_{18}|| \mathrm{Al}_{x} \mathrm{MnO}_{2}$ cell are due to the improved $\mathrm{Al}$ stripping/plating kinetics of the lamella-nanostructured $\mathrm{E}$ $\mathrm{Al}_{82} \mathrm{Cu}_{18}$. As demonstrated in EIS analysis (Fig. $4 \mathrm{~d}$ and Supplementary Fig. 22a, b), the E- $\mathrm{Al}_{82} \mathrm{Cu}_{18}|| \mathrm{Al}_{x} \mathrm{MnO}_{2}$ cell has its $R_{\mathrm{I}}$ and $R_{\mathrm{CT}}$ values to be $\sim 18 \Omega$ and $\sim 1836 \Omega$ smaller than those of $\mathrm{Al}|| \mathrm{Al}_{x} \mathrm{MnO}_{2}$ (Supplementary Fig. 22c, d and Supplementary Table 7). Supplementary Figure 23 shows the self-discharge behavior of $\mathrm{E}-\mathrm{Al}_{82} \mathrm{Cu}_{18}|| \mathrm{Al}_{x} \mathrm{MnO}_{2}$ cell. Similar to the $\mathrm{Al}||$ $\mathrm{Al}_{x} \mathrm{MnO}_{2}$, the $\mathrm{Al}_{82} \mathrm{Cu}_{18}|| \mathrm{Al}_{x} \mathrm{MnO}_{2}$ has an evident voltage drop in the initial $10 \mathrm{~h}$. Owing to the sluggish intercalation kinetics of $\mathrm{Al}^{3+}$ in the $\mathrm{Al}_{x} \mathrm{MnO}_{2}$, the $\mathrm{E}-\mathrm{Al}_{82} \mathrm{Cu}_{18}|| \mathrm{Al}_{x} \mathrm{MnO}_{2}$ displays a voltage plateau in the subsequent $190 \mathrm{~h}$, with a low self-discharge 
rate of $\sim 0.57 \mathrm{mVh}^{-1}$. Moreover, the E- $\mathrm{Al}_{82} \mathrm{Cu}_{18}|| \mathrm{Al}_{x} \mathrm{MnO}_{2}$ cell also exhibits an improved cycling stability when performed by the galvanostatic charge/discharge at $500 \mathrm{~mA} \mathrm{~g}^{-1}$ in the voltage window between 0.5 and $1.8 \mathrm{~V}$ (Supplementary Fig. 24). As shown in Fig. 4 e, it retains $\sim 83 \%$ of the initial capacity after 400 cycles, along with the Coulombic efficiency of $\sim 99 \%$ (Supplementary Fig. 25). In sharp comparison, the $\mathrm{Al} \| \mathrm{Al}_{x} \mathrm{MnO}_{2}$ cell undergoes fast capacity degradation as well as low Coulombic efficiency in tens of cycles probably due to the poor reversibility of monometallic $\mathrm{Al}$ (Fig. 4e and Supplementary Fig. 25). Along with the cell-level capacity of $66.7 \mathrm{mAh} \mathrm{g}^{-1}$ and specific energy of $90.2 \mathrm{Wh} \mathrm{kg}^{-1}$, which are evaluated according to the methodology of practical assessment for aluminum battery technologies ${ }^{25}$, our full E- $\mathrm{Al}_{82} \mathrm{Cu}_{18}|| \mathrm{Al}_{x} \mathrm{MnO}_{2}$ cell outperforms state-of-the-art aluminum batteries (Supplementary Table 8).

\section{Discussion}

In conclusion, we have demonstrated eutectic engineering as an effective strategy to develop highly reversible Al-based alloy anodes, typically lamella-nanostructured $\mathrm{E}-\mathrm{Al}_{82} \mathrm{Cu}_{18}$, for high-performance aqueous rechargeable Al-ion batteries. Triggered by in-situ eutectic solidification reaction, the $\mathrm{E}-\mathrm{Al}_{82} \mathrm{Cu}_{18}$ has an ordered lamellar nanostructure composed of alternating monometallic $\alpha$ - $\mathrm{Al}$ and intermetallic $\mathrm{Al}_{2} \mathrm{Cu}$ nanolamellas, which pair with each other to form periodically localized galvanic couples of $\mathrm{Al} / \mathrm{Al}_{2} \mathrm{Cu}$. By making use of their different corrosion potentials, the less-noble $\alpha$-Al lamellas work as electroactive materials to supply $\mathrm{Al}^{3+}$ charge carriers while the more-noble $\mathrm{Al}_{2} \mathrm{Cu}$ lamellas serve as $2 \mathrm{D}$ nanopatterns to guide highly reversible $\mathrm{Al}$ stripping and plating at low overpotentials, particularly in $\mathrm{N}_{2}$-purged aqueous $\mathrm{Al}(\mathrm{OTF})_{3}$ electrolyte with ultralow oxygen concentration of $0.13 \mathrm{mg} \mathrm{L}^{-1}$. As a consequence, the $\mathrm{E}-\mathrm{Al}_{82} \mathrm{Cu}_{18}$ electrodes exhibit exceptionally $\mathrm{Al}$ stripping/plating stability for more than $2000 \mathrm{~h}$, along with low overpotentials and high energy efficiency. These outstanding electrochemical properties enlist full cells of $\mathrm{E}-\mathrm{Al}_{82} \mathrm{Cu}_{18}|| \mathrm{Al}_{x} \mathrm{MnO}_{2}$ to deliver specific energy of as high as $\sim 670 \mathrm{Wh} \mathrm{kg}^{-1}$ or energy density of $815 \mathrm{Wh} \mathrm{L}^{-1}$ (based on the mass or volume of $\mathrm{Al}_{x} \mathrm{MnO}_{2}$ cathode) and retain $80 \%$ capacity for more than 400 cycles.

\section{Methods}

Preparation of eutectic Al-Cu alloy anodes and $\mathrm{Al}_{\mathbf{x}} \mathrm{MnO}_{2}$ nanosheet cathode. The lamella-nanostructured eutectic $\mathrm{Al}_{82} \mathrm{Cu}_{18}$ alloy $\left(\mathrm{E}-\mathrm{Al}_{82} \mathrm{Cu}_{18}\right)$ ingots were firstly produced by arc melting pure Al $(99.994 \%$, Sinopharm Chemical Reagent Co. Ltd) and $\mathrm{Cu}(99.996 \%$, Sinopharm Chemical Reagent Co. Ltd) metals in an argon atmosphere. During the furnace cooling assisted by circulating water, there takes place a eutectic solidification reaction to form a lamellar nanostructure. The as-prepared E$\mathrm{Al}_{82} \mathrm{Cu}_{18}$ was cut into $\sim 400-\mu \mathrm{m}$-thick sheets along the perpendicular direction of lamellar structure using a diamond wire saw cutting machine (STX-202A), followed by a 7000-mesh sandpaper polishing procedure for further microstructural characterizations and electrochemical measurements. The length and width of $\mathrm{Al}_{82} \mathrm{Cu}_{18}$ alloy are $20 \mathrm{~mm}$ and $10 \mathrm{~mm}$, respectively. The $\mathrm{Al}_{2} \mathrm{Cu}$ intermetallic compound sheets with a thickness of $\sim 400 \mu \mathrm{m}$ were prepared by the same procedure. In comparison, the commercial $\mathrm{Al}$ foils were polished with a 7000-mesh sandpaper to remove surface oxide for use as $\mathrm{Al}$ electrode. The $\mathrm{Al}^{3+}$ preintercalated manganese oxide $\left(\mathrm{Al}_{x} \mathrm{M}-\right.$ $\mathrm{nO}_{2} \cdot n \mathrm{H}_{2} \mathrm{O}$ ) nanosheets were synthesized by a modified hydrothermal method. In a Teflon-lined steel, autoclave contains a mixture of $20 \mathrm{mM} \mathrm{KMnO}_{4}, 20 \mathrm{mM} \mathrm{NH}_{4} \mathrm{Cl}$, and $5 \mathrm{mM} \mathrm{Al}\left(\mathrm{NO}_{3}\right)_{3}$, the hydrothermal synthesis was performed at $150^{\circ} \mathrm{C}$ for $24 \mathrm{~h}$, with a magnetically stirring at a speed of $250 \mathrm{rpm}$. After washing in ultrapure water, the as-prepared $\mathrm{Al}_{x} \mathrm{MnO}_{2} \cdot n \mathrm{H}_{2} \mathrm{O}$ nanosheets were mixed with super-P acetylene black as the conducting agent and poly (vinylidene difluoride) as the binder in a weight ratio of $70: 20: 10$ and then pasted on stainless steel foil $(\sim 20 \mu \mathrm{m}$ thick, Bary Metallic Co., Ltd) with the loading mass of $1.0 \mathrm{mg} \mathrm{cm}^{-2}$ for the use of cathode materials.

Physicochemical characterizations. The electronic microstructures of $\mathrm{E}-\mathrm{Al}_{82} \mathrm{Cu}_{18}$ and $\mathrm{Al}_{2} \mathrm{Cu}$ alloy sheets were characterized by a field-emission scanning electron microscope equipped with an X-ray energy-dispersive spectroscopy (JEOL, JSM$6700 \mathrm{~F}, 8 \mathrm{kV}$ ) and a field-emission transmission electron microscope (JEOL, JEM$2100 \mathrm{~F}, 200 \mathrm{kV}$ ). The metallographic microstructure of $\mathrm{E}-\mathrm{Al}_{82} \mathrm{Cu}_{18}$ alloy was observed on a confocal laser scanning microscope (OLS3000, Olympus) after a chemical etching in a Keller solution. X-ray diffraction measurements of all specimens were performed on a $\mathrm{D} / \mathrm{max} 2500 \mathrm{pc}$ diffractometer with a $\mathrm{Cu} \mathrm{Ka}$ radiation. Raman spectra were measured on a micro-Raman spectrometer (Renishaw) at the laser power of $0.5 \mathrm{~mW}$ in which the laser with a wavelength of $532 \mathrm{~nm}$ was equipped. X-ray photoelectron spectroscopy analysis was conducted on a Thermo ECSALAB 250 with an $\mathrm{Al}$ anode. Charging effects were compensated by shifting binding energies based on the adventitious $\mathrm{C} 1 s$ peak $(284.8 \mathrm{eV}) . \mathrm{O}_{2}$ concentrations and $\mathrm{Cu} / \mathrm{Al}$ ion concentrations in electrolytes were analyzed by portable DO meter (az8403) and inductively coupled plasma optical emission spectrometer (ICP-OES, Thermo electron), respectively.

Electrochemical characterizations. Symmetric coin-type cells of $\mathrm{E}-\mathrm{Al}_{82} \mathrm{Cu}_{18}$, $\mathrm{Al}_{2} \mathrm{Cu}$, and $\mathrm{Al}$ were assembled with their two identical electrodes separated by glass fiber membranes (GFMs) with a pore diameter of $1.2 \mu \mathrm{m}$ and thickness of $260 \mu \mathrm{m}$ in $0.25 \mathrm{~mL} 2 \mathrm{M} \mathrm{Al}(\mathrm{OTF})_{3}$ aqueous solutions with $\mathrm{O}_{2}$ concentrations from 0.13 to $13.6 \mathrm{mg} \mathrm{L}^{-1}$, at $25 \pm 0.5^{\circ} \mathrm{C}$. Therein, the $\mathrm{O}_{2}$ concentrations in the electrolytes were adjusted by purging $\mathrm{N}_{2}$ for $2,0.5$, and $0 \mathrm{~h}$, and $\mathrm{O}_{2}$ for 1 and $2 \mathrm{~h}$, respectively. Electrochemical impendence spectroscopy (EIS) measurements were conducted on as-assembled symmetric cells of $\mathrm{E}-\mathrm{Al}_{82} \mathrm{Cu}_{18}, \mathrm{Al}_{2} \mathrm{Cu}$, and $\mathrm{Al}$ over a frequency range from $100 \mathrm{kHz}$ to $10 \mathrm{mHz}$ (71 points) in quasi-stationary potential at the amplitude of the sinusoidal voltage of $10 \mathrm{mV}$. The electrochemical Al stripping/plating behaviors were measured in as-assembled $\mathrm{E}-\mathrm{Al}_{82} \mathrm{Cu}_{18}, \mathrm{Al}_{2} \mathrm{Cu}$, and $\mathrm{Al}$ symmetric cells at various specific currents. To illustrate their electrochemical stabilities, $\mathrm{Al}$ stripping/plating and EIS measurements were performed on the same symmetric cells during their long-term Al stripping/plating cycles. Fresh full aqueous Al-ion coin cells were constructed with the $\mathrm{E}-\mathrm{Al}_{82} \mathrm{Cu}_{18}$ or $\mathrm{Al}$ sheet as the anode, the stainless-steel foil supported $\mathrm{Al}_{x} \mathrm{MnO}_{2} \cdot n \mathrm{H}_{2} \mathrm{O}$ as the cathode, the GFM as the separator, the $0.25 \mathrm{~mL} 2 \mathrm{M} \mathrm{Al}(\mathrm{OTF})_{3}$ aqueous solution containing $0.2 \mathrm{M} \mathrm{Mn}(\mathrm{OTF})_{2}$ and $\mathrm{O}_{2}$ concentration of $0.13 \mathrm{mg} \mathrm{L}^{-1}$ as the aqueous electrolyte, for measurements of CV, galvanostatic charge/discharge curves, EIS, durability, and self-discharge, respectively, at $25 \pm 0.5^{\circ} \mathrm{C}$. All these electrochemical energy-storage tests were in an open environment, not in a climatic/environmental chamber. CV measurements were conducted on an electrochemical analyzer (Ivium Technology) in the voltage range of 0.5 and $1.9 \mathrm{~V}$ at scan rates from 0.1 to $3 \mathrm{mV} \mathrm{s}^{-1}$. Galvanostatic charge/ discharge curves were collected at different specific currents to demonstrate their rate performance. EIS measurements were performed in the frequency ranges from $100 \mathrm{kHz}$ to $10 \mathrm{mHz}$ (71 points) in quasi-stationary potential at the amplitude of the sinusoidal voltage of $10 \mathrm{mV}$. The durability performance of full cells were evaluated by performing charge/discharge cycles at $500 \mathrm{~mA} \mathrm{~g}^{-1}$ (1 C). Self-discharge measurements were carried out by charging $\mathrm{Al}_{82} \mathrm{Cu}_{18}|| \mathrm{Al}_{x} \mathrm{MnO}_{2}$ and $\mathrm{Al}|| \mathrm{Al}_{x} \mathrm{MnO}_{2}$ full cells to $1.8 \mathrm{~V}$, followed by open-circuit potential self-discharging for $200 \mathrm{~h}$.

Statistics and reproducibility. Experiments were reproducible.

Figure 1e, the experiments were performed twice with similar results.

Figure 1f, the experiments were performed twice with similar results.

Figure 1g, the experiments were performed twice with similar results.

Figure $1 \mathrm{j}$, the experiments were performed twice with similar results.

Figure 3a, the experiments were performed twice with similar results.

Supplementary Figure $13 \mathrm{a}-\mathrm{c}$, the experiments were performed twice with similar results.

Supplementary Figure 14a, b, the experiments were performed twice with similar results.

\section{Data availability}

All data supporting this study and its findings within the article and its Supplementary Information are available from the corresponding authors upon reasonable request.

Received: 1 September 2021; Accepted: 17 January 2022;

Published online: 31 January 2022

\section{References}

1. Dunn, B., Kamath, H. \& Tarascon, J. M. Electrical energy storage for the grid: a battery of choices. Science 334, 928-935 (2011).

2. Tian, Y. et al. Promises and challenges of next-generation "beyond Li-ion" batteries for electric vehicles and grid decarbonization. Chem. Rev. 121, 1623-1669 (2021)

3. Schmuch, R., Wagner, R., Hörpel, G., Placke, T. \& Winter, M. Performance and cost of materials for lithium-based rechargeable automotive batteries. Nat Energy 3, 267-278 (2018).

4. Larcher, D. \& Tarascon, J. M. Towards greener and more sustainable batteries for electrical energy storage. Nat. Chem. 7, 19-29 (2015).

5. Choi, J. W. \& Aurbach, D. Promise and reality of post-lithium-ion batteries with high energy densities. Nat. Rev. Mater. 1, 16013 (2016)

6. Kim, H. et al. Aqueous rechargeable $\mathrm{Li}$ and $\mathrm{Na}$ ion batteries. Chem. Rev. 114 11788-11827 (2014)

7. Li, Y. Q. et al. Dual-phase nanostructuring of layered metal oxides for highperformance aqueous rechargeable potassium ion microbatteries. Nat. Commun. 10, 4292 (2019). 
8. Wang, F. et al. High-voltage aqueous magnesium ion batteries. ACS Cent. Sci. 3, 1121-1128 (2017).

9. $\mathrm{Xu}, \mathrm{Y}$. et al. Vanadium oxide pillared by interlayer $\mathrm{Mg}^{2+}$ ions and water as ultralong-life cathodes for magnesium-ion batteries. Chem 5, 1194-1209 (2019).

10. Elia, G. A. et al. An overview and future perspectives of aluminum batteries. Adv. Mater. 28, 7564-7579 (2016).

11. Zhao, Q., Zachman, M. J., Al Sadat, W. I., Zheng, J., Kourkoutis, L. F. \& Archer, L. Solid electrolyte interphases for high-energy aqueous aluminum electrochemical cells. Sci. Adv. 4, eaau8131 (2018).

12. $\mathrm{Wu}, \mathrm{C}$. et al. Electrochemically activated spinel manganese oxide for rechargeable aqueous aluminum battery. Nat. Commun. 10, 73 (2019).

13. Yuan, D., Zhao, J., Manalastas, W. Jr., Kumar, S. \& Srinivasan, M. Emerging rechargeable aqueous aluminum ion battery: Status, challenges, and outlooks. Nano Mater. Sci. 2, 248-263 (2020).

14. Yan, C. et al. Architecting a stable high-energy aqueous Al-ion battery. J. Am. Chem. Soc. 142, 15295-15304 (2020).

15. Tang, X. et al. A universal strategy towards high-energy aqueous multivalention batteries. Nat. Commun. 12, 2857 (2021)

16. Kundu, D., Adams, B. D., Duffort, V., Vajargah, S. H. \& Nazar, L. F. A highcapacity and long-life aqueous rechargeable zinc battery using a metal oxide intercalation cathode. Nat. Energy 1, 16119 (2016).

17. Pan, H. et al. Reversible aqueous zinc/manganese oxide energy storage from conversion reactions. Nat. Energy 1, 16039 (2016).

18. Ma, L. et al. Realizing high zinc reversibility in rechargeable batteries. Nat. Energy 5, 743-749 (2020).

19. Wang, F. et al. Highly reversible zinc metal anode for aqueous batteries. Nat. Mater. 17, 543-549 (2018)

20. Zhang, N. et al. Materials chemistry for rechargeable zinc-ion batteries. Chem. Soc. Rev. 49, 4203-4219 (2020).

21. Liang, Y., Dong, H., Aurbach, D. \& Yao, Y. Current status and future directions of multivalent metal-ion batteries. Nat. Energy 5, 646-656 (2020).

22. Yuan, X. et al. Latest advances in high-voltage and high-energy-density aqueous rechargeable batteries. Electrochem. Energy Rev. 4, 1-34 (2021).

23. Li, Q. \& Bjerrum, N. J. Aluminum as anode for energy storage and conversion: a review. J. Power Sources 110, 1-10 (2002).

24. Leisegang, T. et al. The aluminum-ion battery: a sustainable and seminal concept? Front. Chem. 7, 268 (2019).

25. Faegh, E., Ng, B., Hayman, D. \& Mustain, W. E. Practical assessment of the performance of aluminum battery technologies. Nat. Energy 6, 21-29 (2021).

26. Lin, M. C. et al. An ultrafast rechargeable aluminum-ion battery. Nature $\mathbf{5 2 0}$, 325-328 (2015).

27. Liu, S. et al. Aluminum storage behavior of anatase $\mathrm{TiO}_{2}$ nanobute arrays in aqueous solution for aluminum ion batteries. Energy Environ. Sci. 5, 9743-9746 (2012).

28. Koketsu, T. et al. Reversible magnesium and aluminum ions insertion in cation-deficient anatase $\mathrm{TiO}_{2}$. Nat. Mater. 16, 1142-1148 (2017).

29. Zou, W. et al. Bismuth oxide: a versatile high-capacity electrode material for rechargeable aqueous metal-ion batteries. Energy Environ. Sci. 9, 2881-2891 (2016).

30. Kumar, S. et al. Investigating FeVO4 as a cathode material for aqueous aluminum-ion battery. J. Power Sources 426, 151-161 (2019).

31. He, S. et al. A high-energy aqueous aluminum-manganese battery. Adv. Funct. Mater. 29, 1905228 (2019).

32. Li, Z., Xiang, K., Xing, W., Carter, W. C. \& Chiang, Y. M. Reversible aluminumion intercalation in Prussian blue analogs and demonstration of a high-power aluminum-ion asymmetric capacitor. Adv. Energy Mater. 5, 1401410 (2015)

33. Liu, S., Pan, G. L., Li, G. R. \& Gao, X. P. Copper hexacyanoferrate nanoparticles as cathode material for aqueous Al-ion batteries. J. Mater. Chem. A 3, 959-962 (2015).

34. Ambroz, F., Macdonald, T. J. \& Nann, T. Trends in aluminum-based intercalation batteries. Adv. Energy Mater. 7, 1602093 (2017)

35. Dong, T., Ng, K. L., Wang, Y., Voznyy, O. \& Azimi, G. Solid electrolyte interphase engineering for aqueous aluminum metal batteries: a critical evaluation. Adv. Energy Mater. 11, 2100077 (2021).

36. Mazurkiewicz, B. \& Piotrowski, A. The electrochemical behavior of the $\mathrm{Al} 2 \mathrm{Cu}$ intermetallic compound. Corr. Sci. 23, 697-707 (1983)

37. Birbilis, N. \& Buchheit, R. G. Electrochemical characteristics of intermetallic phases in aluminum alloy. J. Electrochem. Soc. 152, B140-B151 (2005).

38. Heligman, B. T., Kreder, K. J. III \& Manthiram, A. Zn-Sn interdigitated eutectic alloy anodes with high volumetric capacity for lithium-ion batteries. Joule 3, 1051-1063 (2019).

39. Wang, S. B. et al. Lamella-nanostructured eutectic zinc-aluminum alloys as reversible and dendrite-free anodes for aqueous rechargeable batteries. Nat. Commun. 11, 1634 (2020).

40. Cahn, R. W. \& Haasen, P. Physical Metallurgy (Netherlands, 1996).

41. Jackson, K. A. \& Hunt, J. D. Lamellar and rod eutectic growth. Metal. Soc. AIME 236, 1129-1141 (1966).
42. Scully, J. R., Knight, T. O., Buchheit, R. G. \& Peebles, D. D. Electrochemical characteristics of $\mathrm{Al}_{2} \mathrm{Cu}, \mathrm{Al}_{3} \mathrm{Ta}$ and $\mathrm{Al}_{3} \mathrm{Zr}$ intermetallic phases and their relevancy to the localized corrosion of $\mathrm{Al}$ alloys. Corr. Sci. 35, 185-195 (1993).

43. Kolics, A., Besing, A. S., Baradlai, P., Haasch, R. \& Wieckowski, A. Effect of $\mathrm{pH}$ on thickness and ion content of the oxide film on aluminum in $\mathrm{NaCl}$ media. J. Electrochem. Soc. 148, B251-B259 (2001).

44. Scheitenberger, P., Brimaud, S. \& Lindén, M. XRD/Raman spectroscopy studies of the mechanism of (de)-intercalation of $\mathrm{Na}^{+}$from/into highly crystalline birnessite. Mater. Adv. 2, 3940-3953 (2021).

45. Julien, C. et al. Raman spectra of birnessite manganese dioxides. Solid State Ion. 159, 345-356 (2003).

46. Baddour-Hadjean, R. \& Pereira-Ramos, J. Raman microspectrometry applied to the study of electrode materials for lithium batteries. Chem. Rev. 110, 1278-1319 (2010).

47. Zhai, X. Z. et al. Layered birnessite cathode with a displacement/intercalation mechanism for high-performance aqueous zinc-ion batteries. Nano-Micro Lett. 12, 56 (2020).

48. Yang, Z. et al. Probing the release and uptake of water in $\alpha-\mathrm{MnO}_{2} \cdot x \mathrm{H}_{2} \mathrm{O}$. Chem. Mater. 29, 1507-1517 (2017).

49. Smith, D. W. Ionic hydration entralpies. J. Chem. Educ. 54, 540-542 (1977).

50. Taberna, P. L., Mitra, S., Poizot, P., Simon, P. \& Tarascon, J. M. High rate capability $\mathrm{Fe}_{3} \mathrm{O}_{4}$-based $\mathrm{Cu}$ nano-architectured electrodes for lithium-ion battery applications. Nat. Mater. 5, 567-573 (2006).

51. Gogotsi, Y. \& Simon, P. True performance metrics in electrochemical energy storage. Science 334, 917-918 (2011).

\section{Acknowledgements}

This work was supported by National Natural Science Foundation of China (No. 51871107, 52130101, and 51631004), Chang Jiang Scholar Program of China (Q2016064), the Program for JLU Science and Technology Innovative Research Team (JLUSTIRT, 2017TD-09), the Fundamental Research Funds for the Central Universities, and the Program for Innovative Research Team (in Science and Technology) in University of Jilin Province.

\section{Author contributions}

X.Y.L. and Q.J. conceived and designed the experiments. Q.R., H.S., H.M., S.P.Z., W.B.W, W.Z., and Z.W. carried out the fabrication of materials and performed the electrochemical measurements and microstructural characterizations. X.Y.L., Q.R., H.S., and Q.J. wrote the paper, and all authors discussed the results and commented on the manuscript.

\section{Competing interests}

The authors declare no competing interests.

\section{Additional information}

Supplementary information The online version contains supplementary material available at https://doi.org/10.1038/s41467-022-28238-3.

Correspondence and requests for materials should be addressed to Xing-You Lang or Qing Jiang.

Peer review information Nature Communications thanks Tilmann Leisegang, and the other, anonymous, reviewer(s) for their contribution to the peer review of this work. Peer reviewer reports are available

Reprints and permission information is available at http://www.nature.com/reprints

Publisher's note Springer Nature remains neutral with regard to jurisdictional claims in published maps and institutional affiliations.

Open Access This article is licensed under a Creative Commons Attribution 4.0 International License, which permits use, sharing, adaptation, distribution and reproduction in any medium or format, as long as you give appropriate credit to the original author(s) and the source, provide a link to the Creative Commons license, and indicate if changes were made. The images or other third party material in this article are included in the article's Creative Commons license, unless indicated otherwise in a credit line to the material. If material is not included in the article's Creative Commons license and your intended use is not permitted by statutory regulation or exceeds the permitted use, you will need to obtain permission directly from the copyright holder. To view a copy of this license, visit http://creativecommons.org/ licenses/by/4.0/

(C) The Author(s) 2022 